\title{
On the origins of water masses exported along both sides of Greenland: A Lagrangian model analysis
}

\author{
C. Lique, ${ }^{1}$ A. M. Treguier, ${ }^{1}$ B. Blanke, ${ }^{1}$ and N. Grima ${ }^{1}$ \\ Received 6 February 2009; revised 24 November 2009; accepted 28 December 2009; published 21 May 2010.
}

[1] The origin of the water masses exported from the Arctic to the North Atlantic along both sides of Greenland is investigated using an original numerical method. A quantitative Lagrangian analysis is applied to the monthly climatological 3-D output of a global ocean/sea ice high-resolution model. It allows quantification of the different branches of the export to the North Atlantic, as well as related timescales and water mass transformations. In the model, the outflow through Davis Strait consists in equal parts of Pacific and Atlantic water, whilst the export through Fram Strait consists almost fully of Atlantic water (contrary to observations). Pacific water is transferred quickly ( $\mathrm{O}(10$ years)) to the North Atlantic through the Beaufort Gyre, where gradual warming and salinification occur. Atlantic water exiting in the surface layer along both sides of Greenland remains about 10 years in the Arctic Basin and undergoes cooling and significant freshening. Below the surface water, Atlantic water exiting through the intermediate and deep layers in Fram Strait follows different pathways in the Arctic, with trajectories being subject to topography constraints. The travel time depends strongly on the pathway (from 1 to 1000 years). The intermediate outflow consists mainly of water entering the Arctic at Fram Strait, while half the deep outflow is composed of water from the Barents Sea. We find that the Barents Sea Branch, which contributes to both the outflows at Fram and Davis straits, is almost fully transformed after a year due to heat exchanges with the very cold atmosphere (in the Barents Sea).

Citation: Lique, C., A. M. Treguier, B. Blanke, and N. Grima (2010), On the origins of water masses exported along both sides of Greenland: A Lagrangian model analysis, J. Geophys. Res., 115, C05019, doi:10.1029/2009JC005316.

\section{Introduction}

[2] The large-scale circulation of the Arctic Ocean has been known for a long time [Nansen, 1902; Coachman and Aagaard, 1974]. Cold and relatively fresh Pacific water enters the Arctic Ocean through Bering Strait. A part is swept into the Beaufort Gyre, in the Canadian Basin, and exits into the North Atlantic Ocean on the western side of Greenland, through the Canadian Arctic Archipelagos (CAA) and then through Davis Strait, whilst a second part follows the shelf break along the Canadian Coast and eventually exits along both sides of Greenland through Davis Strait and Fram Strait. At the same time, warm and dense water enters the Arctic Ocean from the Atlantic Ocean along two main pathways: Fram Strait and the Barents Sea. However, the fate of these two branches of Atlantic water is different. The part crossing Fram Strait with the West Spitsbergen Current (hereafter called the Fram Strait Branch) remains beneath colder and fresher water layers. This prevents the heat in the Atlantic layer from melting sea

\footnotetext{
${ }^{1}$ Laboratoire de Physique des Océans, UMR 6523, UBO, CNRS, IFREMER, IRD, Plouzane, France.

Copyright 2010 by the American Geophysical Union. 0148-0227/10/2009JC005316
}

ice as well as from contact with the atmosphere. On the other hand, Atlantic water taking a route through the Barents Sea (hereafter called the Barents Sea Branch) loses a part of its heat by contact with the colder atmosphere, and undergoes strong modifications. As the two branches join in the St. Anna Trough, they carry on waters with contrasting properties, that will thus follow different pathways in the Arctic Basin, and eventually come back to the North Atlantic mainly through Fram Strait, and, to some extent, through Davis Strait.

[3] However, our understanding of the Arctic dynamics remains crude and fragmented, and several major questions are in abeyance in the literature. Some studies provide us with a partial or qualitative circulation scheme [Rudels et al., 1994; Jones et al., 1995; Steele et al., 2004; Karcher et al., 2007], but the relative contributions of the different circulation branches, their associated water mass modifications as well as the order of magnitude of their residence times still need to be determined. The role of the Barents Sea in modifying the Atlantic inflow has been pointed out by Gerdes and Schauer [1997] but the mechanisms at play there are still not clearly established. These questions seem hard to address with the few available observations or a classical modeling approach using Eulerian fields. A recent effort has focused on overcoming the lack of knowledge 
regarding the Arctic circulation, through international observational and modeling programs, such as AOMIP (Arctic Ocean Model Intercomparison Project [Proshutinsky et al., 2005]) or DAMOCLES (Developing Arctic Modeling and Observing Capabilities for Long-term Environmental Studies; http://www.damocles-eu.org). A chemical observational approach has also been recently used to try to distinguish and follow the journey of the different water masses exported to the North Atlantic (runoff, Pacific water, Atlantic water), since their chemical composition makes them clearly recognizable [Jones et al., 1998, 2003; Taylor et al., 2003; Falck et al., 2005]. However, direct measurements are still too sparse both in time and space to allow a quantification of the origin of the Arctic outflow to the North Atlantic. At the same time, an important effort has also been made to monitor and model the exchanges between the Arctic Ocean and the Nordic Seas, as "the signal of Arctic change is expected to have its major climatic impact by reaching south through subarctic seas, either side of Greenland, to modulate the Atlantic thermohaline conveyor" [Dickson et al., 2008]. It has been suggested [Mauritzen, 1996; Holloway and Proshutinsky, 2007] that the Arctic/North Atlantic exchanges could have a more important role in the global "conveyor" than just influencing it. The Arctic circulation and related water mass transformations are an important component of the global conveyor that fully invades the Arctic.

[4] In the present study, we use an original approach that allows us to connect these very important Arctic/North Atlantic exchanges with the circulation inside the Arctic, taking advantage of recent progress in numerical modeling. Here we aim at determining the origins of the Arctic waters exported along both sides of Greenland, and at quantifying the water mass modifications that occur in the Arctic Ocean in a numerical model. Lagrangian diagnoses are derived from the velocity and the temperature and salinity fields of a high-resolution global sea ice/ocean simulation in order to track the motion of selected water masses. The same simulation was used in a companion paper [Lique et al., 2009] to study the variability of the freshwater exchanges from the Arctic to the North Atlantic. For this latter issue, the model behavior was shown to be close to observations, even though more model validation is needed and will be presented here. Our Lagrangian analysis provides a quantitative picture of the mean large-scale circulation scheme for the Arctic Ocean, and allows to separate the different branches of circulation as well as their associated water mass transformations and time scales. This study will help to understand the mean state of the Arctic Ocean, which is a key point before understanding variability and trends in the region.

[5] Such a Lagrangian analysis has already been carried out successfully in different Ocean General Circulation Models (OGCM). The method is presented in detail and discussed by Blanke and Raynaud [1997] and Blanke et al. [1999]. It has been already used to describe the general organization of the global ocean circulation [Blanke et al., 2001; Speich et al., 2001] or to study the salinity modifications associated with the circulation in the Atlantic [Blanke et al., 2002, 2006]. A recent study [Koch-Larrouy et al., 2008] used the same model setup (but in a regional configuration) to study the circulation and the water mass transformations in the Indonesian Seas. Our work is based on these previous studies for which the Lagrangian method has shown credible consistency and efficiency.

[6] The remainder of this paper is organized as follows. The numerical tools are briefly presented in section 2 . Model performance in the Arctic area is evaluated in section 3, as we validate the mean simulated Arctic with in situ observations and indications given by other modeling studies. Sections 4 and 5 deal with the Lagrangian results on Arctic dynamics (section 4) and the water mass transformations in the Arctic (section 5). The influence of the Arctic Oscillation (AO) on the circulation scheme we propose is discussed in section 6. A conclusion is given in section 7 .

\section{Numerical Tools}

\subsection{Ocean Model}

[7] The global ORCA025 coupled ocean/sea ice model configuration developed for the DRAKKAR project [The DRAKKAR Group, 2007] is used to perform the simulation. An overall description of the model and its numerical details are given by Barnier et al. [2006]. This model configuration uses a global tripolar grid with $1442 \times 1021$ grid points on the horizontal and 46 vertical levels. Vertical grid spacing is finer near the surface $(6 \mathrm{~m})$ and increases with depth to $250 \mathrm{~m}$ at the bottom. Horizontal resolution is $27.75 \mathrm{~km}$ at the equator, $13.8 \mathrm{~km}$ at $60^{\circ} \mathrm{N}$, and gets to $10 \mathrm{~km}$ in the Arctic Ocean. The ocean/sea ice code is based on the NEMO framework version 1.9. [Madec, 2008]. It uses a partial step representation of the bottom topography and a momentum advection scheme that both yielded a better representation of the ocean dynamics [Le Sommer et al., 2009]. Parameterizations include a Laplacian mixing of temperature and salinity along isopycnals, a horizontal biharmonic viscosity, and a turbulence closure scheme (TKE) for vertical mixing. The bathymetry is derived from the 2 min resolution Etopo 2 bathymetry file of NGDC (National Geophysical Data Center). The sea ice model is the Louvain-la-Neuve model (LIM), which is a dynamic thermodynamic model specifically designed for climate studies. A detailed description is given by Timmermann et al. [2005].

[8] A complete description of our simulation is given by Molines et al. [2006]. It is interannual and runs from 1958 to 2001 with no spin-up. Initialization uses data from the Polar Science Center Hydrographic T/S Climatology (PHC [Steele et al., 2001]). The forcing data set is a blend of data from various origins at different frequencies referenced as DFS3 by Brodeau et al. [2010]. Precipitation and radiation come from the CORE data set assembled by Large and Yeager [2004], at monthly and daily frequency, respectively, based on satellite observations when available. A climatology of the same satellite data set is used for the early years up to 1979 and 1984. Air temperature, humidity and wind speed are 6 hour fields from the ECMWF ERA40 reanalysis. Turbulent fluxes (wind stress, latent and sensible heat fluxes) are estimated using the CORE bulk formula [Large and Yeager, 2004]. River runoff rates are prescribed using the Dai and Trenberth [2002] climatological data set. To avoid an excessive model drift, we add a relaxation of sea surface salinity to the PHC climatology. The coefficient $(0.167 \mathrm{~m} / \mathrm{d})$ amounts to a decay time of 60 days for $10 \mathrm{~m}$ of water depth; under the ice cover, the restoring coefficient is five times stronger. This choice was made within the 
DRAKKAR consortium because of problems encountered with earlier versions of the forcing data, especially in the Weddell Sea. We acknowledge that this restoring is a strong constraint on our model solution and thus the analysis presented in this paper is affected by this constraint. We have considered using a twin experiment that has been carried ou with no relaxation under sea ice (W. Hazeleger and S. Drijfhout, personal communication, 2009), but the drift of water mass properties in the Arctic was found unacceptable for the purpose of the present paper.

[9] To run our Lagrangian diagnoses, a climatological year has been built by averaging month by month the monthly means of the simulation from 1980 to 2001. The first 22 years of the simulation have been excluded, when the model adjustment is larger in the Arctic Ocean (see Lique et al. [2009] for a quantification of the model drift). Interannual variability as well as high-frequency variability (finer than 1 month) are thus excluded from our analysis.

\subsection{Lagrangian Method}

[10] The off-line mass preserving Lagrangian ARIANE scheme is used for this study (http://www.univ-brest.fr/lpo/ ariane/). A description of the algorithm is given by Döös [1995] and Blanke and Raynaud [1997]. Water masses are represented by numerous small water parcels (particles) carrying an infinitesimal transport and seeded on given geographical sections. As the algorithm respects water mass incompressibility, each particle conserves its infinitesimal volume along its trajectory. It is integrated with time until it reaches geographical interception sections. The mass transfer between two given sections can thus be determined. The idea is more to describe the large-scale circulation, for instance by computing horizontal streamlines [Blanke et al., 1999], than to compute the most realistic individual trajectories. In all our experiments, the maximum transport carried by a particle is fixed to $10^{-3} \mathrm{~Sv}$. This allows us to define our Lagrangian transports with accuracy better than $10^{-3} \mathrm{~Sv}$ [Valdivieso Da Costa and Blanke, 2004].

[11] Along its trajectory, a given particle will show changing properties (salinity and temperature), as given by the local Eulerian fields of the ocean model. The Lagrangian scheme does not consider turbulent motions in the trajectory calculations, but, as the ocean model parametrizes such effects, the signature of $\mathrm{T} / \mathrm{S}$ evolutions along the computed trajectories can be found and the water mass transformations can be quantified. Since we compute our Lagrangian diagnoses from monthly mean fields, we assume that velocity and tracer fluctuations, and their correlations, are small over periods shorter than monthly climatological means. Variations of temperature and salinity along a trajectory then correspond mostly to the mean effect of direct warming by the solar heat flux, run-off, precipitation and evaporation processes, and to the mean lateral and vertical turbulent diffusion in the model. The access of the information for each individual particles (their infinitesimal transport as well as their $\mathrm{T} / \mathrm{S}$ property) at their entrance and exit sections allows the calculation of heat and freshwater fluxes.

\section{Simulated Arctic Ocean}

[12] As already shown by studies based on the same Lagrangian method [Koch-Larrouy et al., 2008; Friocourt et al., 2005], the degree of confidence one can grant to the Lagrangian interpretation depends on the overall credibility of the Eulerian fields. Three specific issues will be addressed in this section, in order to assess the model performance in the Arctic Ocean: the exchanges by advection with the subpolar area, the circulation and the representation of the water masses in the Arctic Ocean. We define the Arctic Ocean as the area enclosed by the following transects across ocean straits (Figure 1): the Bering Strait, a section across the Barents Sea between Norway and Svalbard Island (following the $20^{\circ} \mathrm{E}$ meridian), the Fram Strait and the Davis Strait. These four sections will be used as intercepting sections in our Lagrangian experiments.

\subsection{Exchanges}

[13] The mean values of the simulated exchanges of mass, liquid freshwater, sea ice and heat across the four sections enclosing the Arctic Basin over the period 1980-2001 are given in Table 1. The freshwater transport is computed with $34.8 \mathrm{psu}$ as a reference according to Aagaard and Carmack [1989], and the heat transport is referenced to $-0.1{ }^{\circ} \mathrm{C}$ according to Aagaard and Greisman [1975]. Model values of the transports of mass and freshwater (as liquid and sea ice) have been discussed by Lique et al. [2009]. Note that the model estimates in Table 1 may differ from those given by Lique et al. [2009] because the period considered is a different (1980-2001 here versus 1965-2002 in Lique et al.'s [2009] study) and the control sections considered may be shifted by a few grid points.

[14] The circulation across the different sections matches fairly well some available observations, despite a $20 \%$ overestimate of the transport (and thus of the liquid freshwater transport) through Bering Strait, compared to the estimate of Woodgate et al. [2006]. The heat flux through this strait is also consequently too large: $4.9 \times 10^{20} \mathrm{~J} / \mathrm{y}$ versus $1-3.10^{20} \mathrm{~J} / \mathrm{y}$ in Woodgate et al.'s [2006] study, with a reference temperature equal to $-1.9^{\circ} \mathrm{C}$ in both calculations. Exchanges through Davis Strait are consistent with direct estimations given by Cuny et al. [2005] (net volume, freshwater, and heat transport are estimated to $-2.6 \pm 1.0 \mathrm{~Sv}$, $-92 \pm 34 \mathrm{mSv}$, and $18 \pm 17 \times 10^{12} \mathrm{~W}$ relative to $0^{\circ} \mathrm{C}$, respectively, our modeled heat net transport being $13.7 \times$ $10^{12} \mathrm{~W}$ with the same reference). Across Fram Strait, the southward flowing East Greenland Current (EGC) exports a large amount of freshwater. Concurrently, heat is brought northward by the West Spitsbergen Current (WSC) in the eastern part of the strait. Modeled volume and freshwater exchanges have been shown to be in the range of uncertainty of the different observational estimates, although weaker than the estimation by Schauer et al. [2004] and Lique et al. [2009], and the heat flux is also consistent with the estimate of Schauer et al. [2004] (between 16 and $41.10^{12} \mathrm{~W}$, depending on the year considered). Relative to our chosen reference temperature and salinity, the simulated transport across the Barents section represents a sink of freshwater and a source of heat for the Arctic Ocean. Our simulation results are close to those obtained by Maslowski et al. [2004] with their model and within the range of values given in the review of observations by Simonsen and Haugan [1996]. 


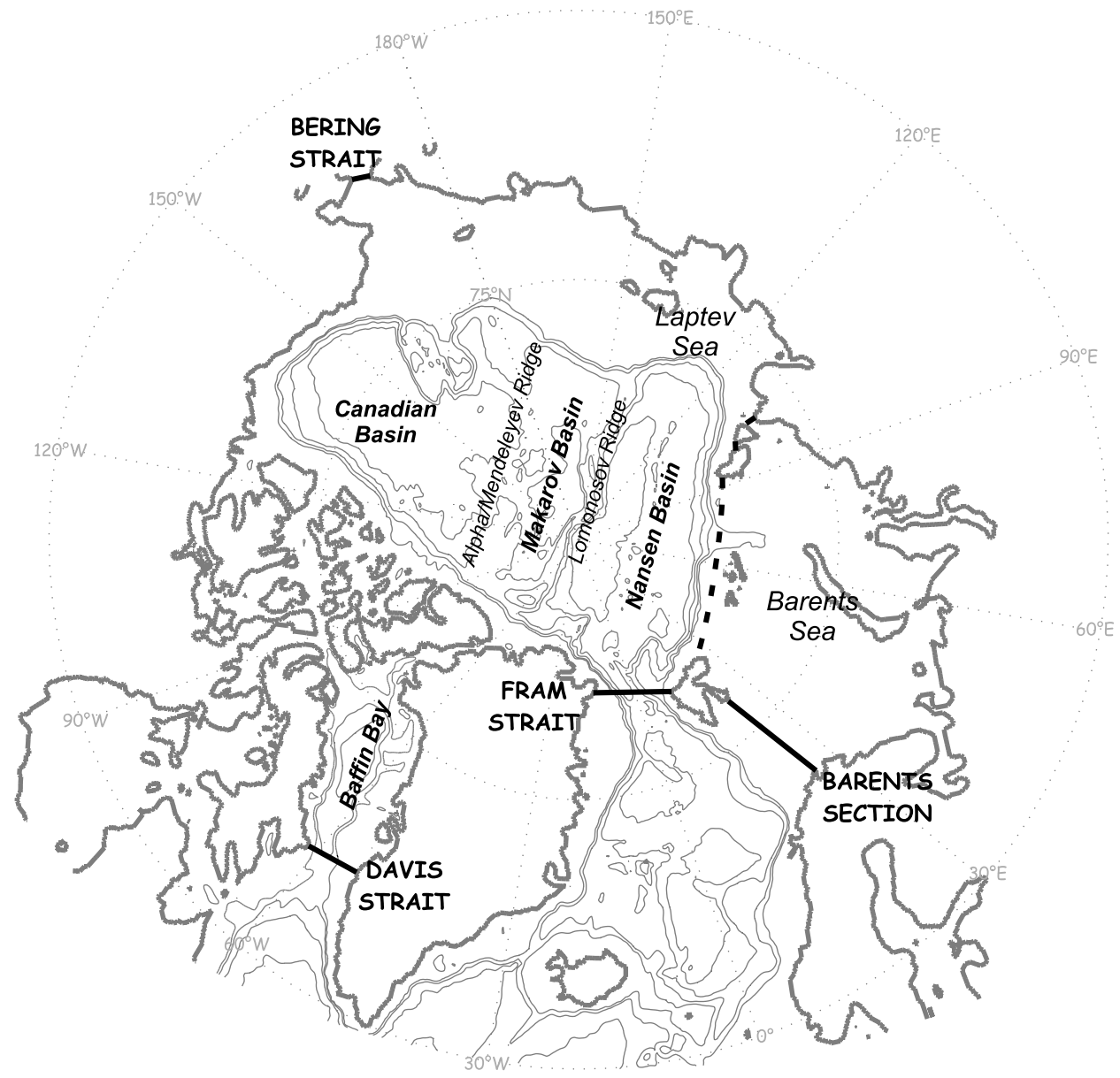

Figure 1. Arctic Ocean and localization of the main place names used in the text. The four sections enclosing the domain of the Lagrangian experiments are shown as thick lines. The additional section used in section 5 is drawn as a dashed line. Bathymetry contours 500, 1000, 2000, 3000, 4000, and $5000 \mathrm{~m}$ are drawn with thin lines.

\subsection{Mean Circulation}

[15] No direct measurement of sea surface height (SSH) variations can be done in the Arctic Ocean because of sea ice and the sea ice drift gives only qualitative information about the surface circulation (see Lique et al. [2009] for plots of the mean surface circulation and sea ice drift in the model). It is therefore difficult to determine the surface circulation, and even more difficult to sketch a general picture of the dynamics in the basin from direct observations.
[16] Figure 2 shows the mean barotropic streamfunction in the Arctic Ocean calculated in our simulation. A classical pattern stands out, with two distinct structures in the two main basins. A cyclonic circulation can be seen in the Eurasian basin, with a maximum of $9 \mathrm{~Sv}$, whereas an anticyclonic structure dominates the Canadian side, with a weaker maximum intensity around $2 \mathrm{~Sv}$.

[17] The diversity of model results for the barotropic streamfunction in the Arctic Ocean is shown by Steiner et

Table 1. Mean Volume, Freshwater, Heat, and Sea Ice Exchanges From the Arctic Ocean to the Subpolar Area Over the Period $1980-2001^{\mathrm{a}}$

\begin{tabular}{|c|c|c|c|c|c|}
\hline & Contribution & Bering Strait & Barents Section & Davis Strait & Fram Strai \\
\hline \multirow[t]{3}{*}{ Mass transport (Sv) } & net & 1.3 & 2.9 & -2.6 & -1.6 \\
\hline & inflow & 1.3 & 4.1 & 0.6 & 3.9 \\
\hline & outflow & 0 & -1.2 & -3.2 & -5.5 \\
\hline \multirow{3}{*}{ Freshwater transport $(\mathrm{mSv})$} & net & 95.2 & -8.1 & -123.8 & -47.6 \\
\hline & inflow & 95.2 & -9.1 & 4.4 & -7.5 \\
\hline & outflow & 0 & 1.0 & -127.2 & -40.1 \\
\hline \multirow[t]{3}{*}{ Heat transport $\left(10^{12} \mathrm{~W}\right)$} & net & 5.4 & 71.6 & 12.6 & 24.4 \\
\hline & inflow & 5.4 & 85.5 & 10.4 & 30.0 \\
\hline & outflow & 0 & -13.9 & 2.2 & -5.6 \\
\hline Sea ice volume $\left(10^{3} \mathrm{~km}^{3} / \mathrm{y}\right)$ & & 0.043 & -0.25 & -0.29 & -3.0 \\
\hline
\end{tabular}

${ }^{a}$ Inflow and outflow directions refer to the Arctic Ocean. See text for the definition of freshwater and heat transports. 


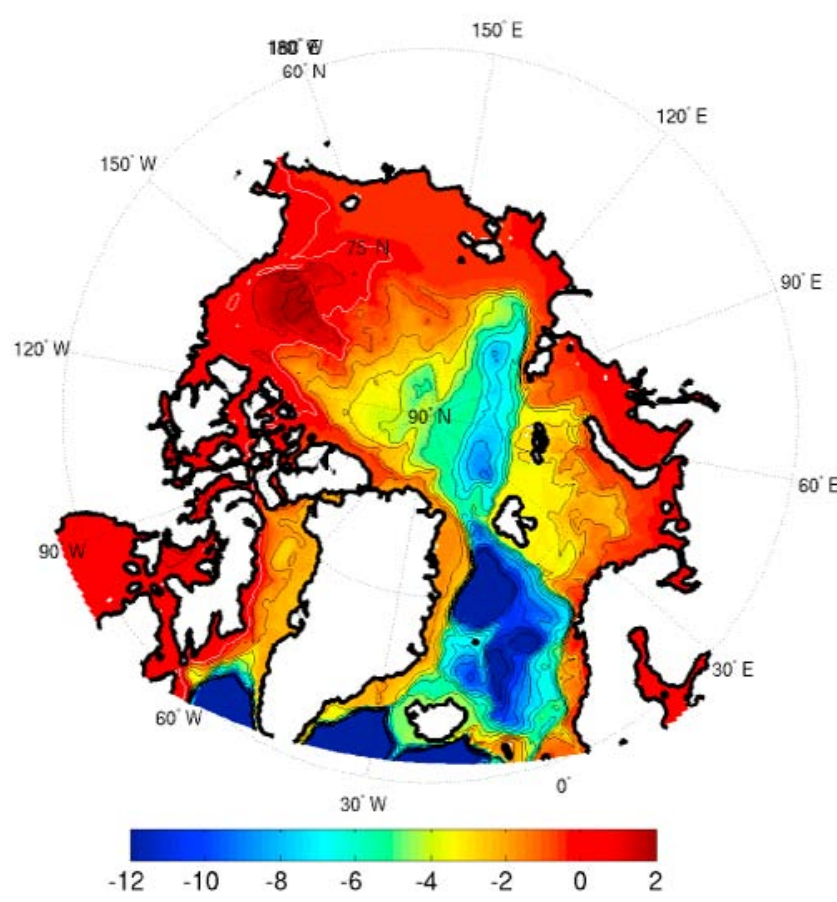

Figure 2. Model annual mean barotropic stream function in Sv. The contour interval is $1 \mathrm{~Sv}$.

al. [2004], for example, as they compare the mean streamfunctions from several models having taken part in the AOMIP project (see their Figure 2). They show that the choice of a parametrization for the eddy-topography interactions as well as the system of coordinates lead to important differences in the simulated Arctic dynamics by the different models. In our model, the circulation in the Eurasian Basin has a higher intensity than any of the models presented by Steiner et al. [2004]. The most important difference between the model results is the circulation found in the Canadian basin, where the streamfunction has positive or negative sign depending on the model. As a matter of fact, in this basin, the Beaufort Gyre is dominating the surface clockwise circulation, whilst the deeper circulation is counterclockwise, due to the influence of topography [Holloway et al., 2007]. The sign of the streamfunction for the flow integrated from the bottom to the surface then depends on the relative intensity of the Beaufort Gyre and of the deep circulation, and also on the depth of the circulation inversion, which takes place around $300 \mathrm{~m}$ in our simulation. This is consistent with the observation of an about $300 \mathrm{~m}$ vertical expansion of the Beaufort Gyre [Proshutinsky et al., 2002].

\subsection{Water Mass Representation}

[18] Figure 3 compares the annual mean freshwater and heat contents integrated over the upper $1000 \mathrm{~m}$ for the model and the PHC climatology [Steele et al., 2001]. The same comparison is done by Steiner et al. [2004] for a few AOMIP models.

[19] The model and the climatology both show warm and salty Atlantic water entering the Arctic Ocean via Fram Strait and the Barents Sea. However, the simulated waters in the Nansen Basin seem warmer and slightly fresher than in the climatology, suggesting an overestimation in our model of the part of the inflow through Fram Strait that reaches the interior of the Arctic. This is supported by the large values of the streamfunction found in this basin. In the Canadian Basin, a large amount of freshwater is stored in the Beaufort Gyre, as predicted and discussed by Proshutinsky et al. [2002]. The general pattern of the modeled freshwater content matches well the climatology, even though the maximum present in the Beaufort Gyre is higher in the model. At the same time, modeled water properties in the Canadian Basin are warmer than in the climatology, with differences ranging from 1 to $3 \mathrm{GJ} \mathrm{m}^{-2}$. The overestimation of the simulated freshwater and heat contents in the Canadian Basin are logically linked to the overestimation of the freshwater and heat fluxes through Bering Strait, as Pacific water spreads over the Beaufort Gyre.

[20] The modeled distribution of heat and freshwater does not show a clear front that would correspond to the Lomonosov Ridge, as in the climatology. Some part of the difference could be explained by an underestimated flow along the Lomonosov Ridge in our model, due to underestimation of the interaction between eddies and bottom topography (the so-called "Neptune effect" of Holloway [1992] whose parametrization by Nazarenko et al. [1998] leads to an intensification of the returning flow along the Lomonosov Ridge). In the model, the front is thus too weak compared to observations. Moreover, Ekwurzel et al. [2001] shows that the front of temperature and salinity between Atlantic water and Pacific water shifted from the Lomonosov Ridge in 1991 to the Mendeleyev Ridge in 1994, and this shift is linked to the North Atlantic Oscillation. Annual mean plots of heat and freshwater content (not shown) reveal that the front displacement between 1991 and 1994 is fairly well represented in the model, and that the position of the front is highly variable at interannual scale. This could explain another part of the difference between the patterns of heat and freshwater contents, as the mean front position strongly depends on the period considered.

\subsection{Definition of the Different Layers}

[21] Figure 4 shows the averaged profiles of salinity, temperature and density referenced to the surface across Davis Strait and Fram Strait. The water masses in both straits are qualitatively well represented by the model, as discussed by Lique et al. [2009]. These profiles may be qualitatively compared with in situ profiles presented by Cuny et al. [2005] (Davis Strait) and Fahrbach et al. [2001] (Fram Strait).

[22] We decided to split up the total export across Fram Strait into three density classes, the separation being done by the 27.8 and 28.05 isopycnals. This choice respects the usual distinction made in the literature between the circulation of the upper [Karcher and Oberhuber, 2002; Steele et al., 2004], intermediate [Rudels et al., 1994; Smethie et al., 2000] and deep layers [Jones et al., 1995]. We assume that the 27.8 isopycnal is a reasonable lower limit of the halocline, as we find it between depths 200 and $400 \mathrm{~m}$. The 28.05 isopycnal is around $1500 \mathrm{~m}$ depth, which is close to the upper limit of the Lomonosov Ridge and often used to distinguish between the intermediate and deep waters 


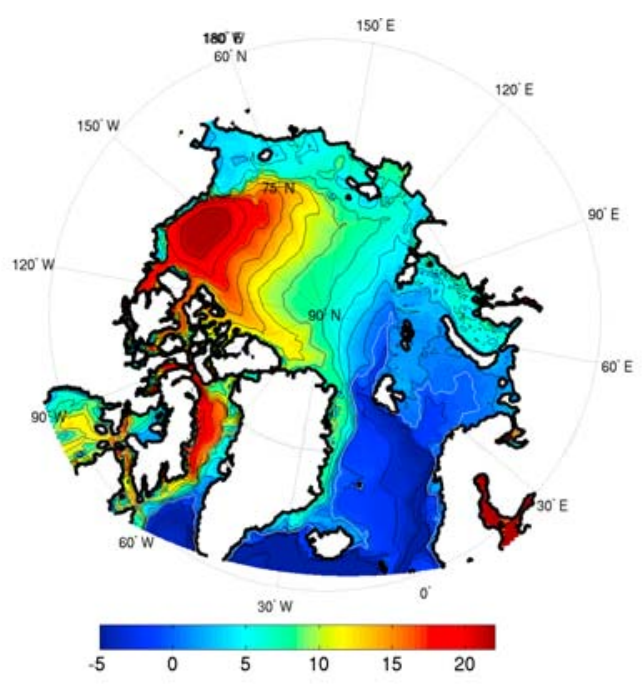

(a)

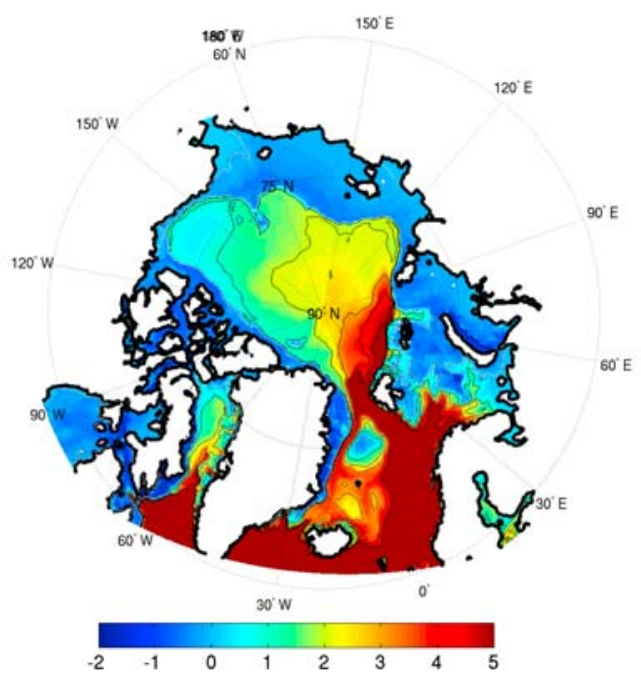

(c)

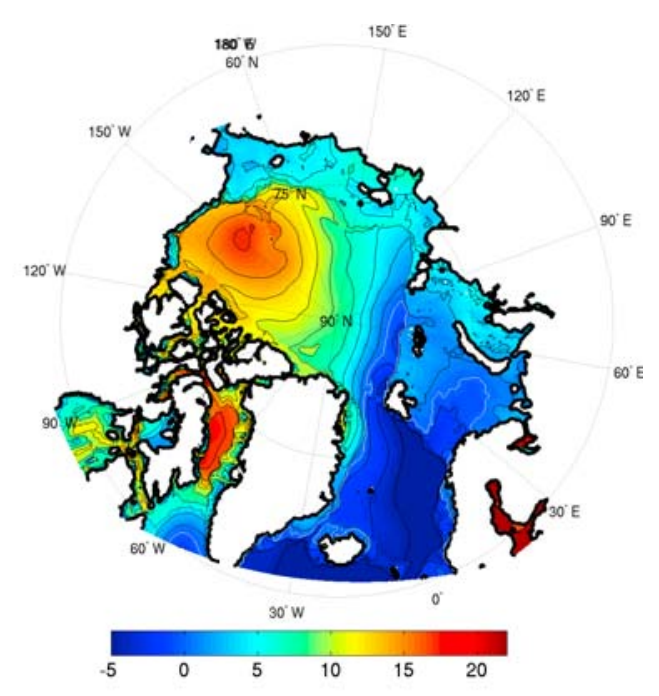

(b)

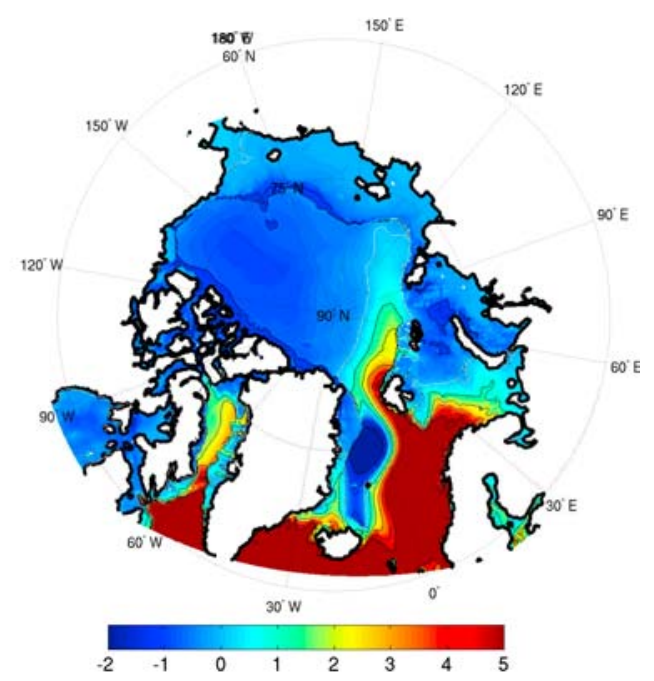

(d)

Figure 3. Model annual mean (a) freshwater content (in $\mathrm{m}$ ) and (c) heat content (in GJ $\mathrm{m}^{-2}$ ) over the upper $1000 \mathrm{~m}$. (b and d) Same as Figures 3a and 3c but for the PHC climatology. The freshwater content and the heat content are referenced to $34.8 \mathrm{psu}$ and $0^{\circ} \mathrm{C}$.

[Smethie et al., 2000]. We also consider that the water exported through Davis Strait does not need to be separated into different density classes, as Davis Strait is only $400 \mathrm{~m}$ deep, and thus we will consider all exports as surface water, their density being under 27.8 .

\section{Circulation Scheme of the Arctic Ocean}

[23] This section aims at establishing a quantitative scheme of the circulation in the Arctic Ocean, as well as related time scales. We inseminate particles at Fram Strait and Davis Strait during 1 full year. Initial positions are regularly distributed both in time (still within the same 30 day interval and then repeated for all months) and space (along the vertical and lateral extend of each gridcell). The number of particles in each cell is defined by the constraint about the maximum transport imposed on one single particle (in our case, $10^{-3} \mathrm{~Sv}$ ). Each particle is allotted a weight equal to a fraction of the local outflow, and keeps its infinitesimal transport all along its trajectory. Particles are integrated backward in time until they reach one of the four sections enclosing our Arctic Basin (see Figure 1). Trajectory calculations are carried out by repeating the same monthly "climatological year" until the slowest particle comes out the domain. About 100000 particles are introduced at Davis Strait, and twice more at Fram Strait.

[24] Equivalent backward experiments with particles inseminated at Bering Strait and over Barents section have shown that no particle exits the Arctic Ocean through Bering Strait, and that all the particles exiting through the Barents section originate from the very same section and remain in the Barents Sea for a short residence time. Such circulations will then be excluded from our analysis. 
(a)

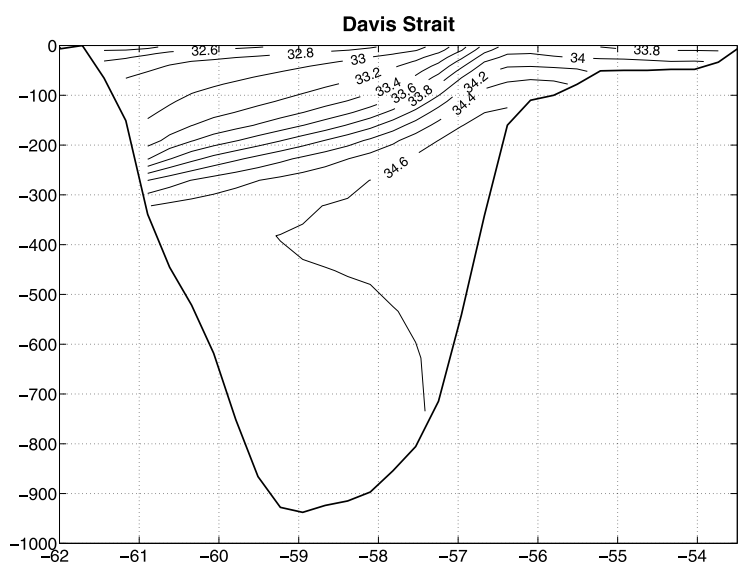

(c)
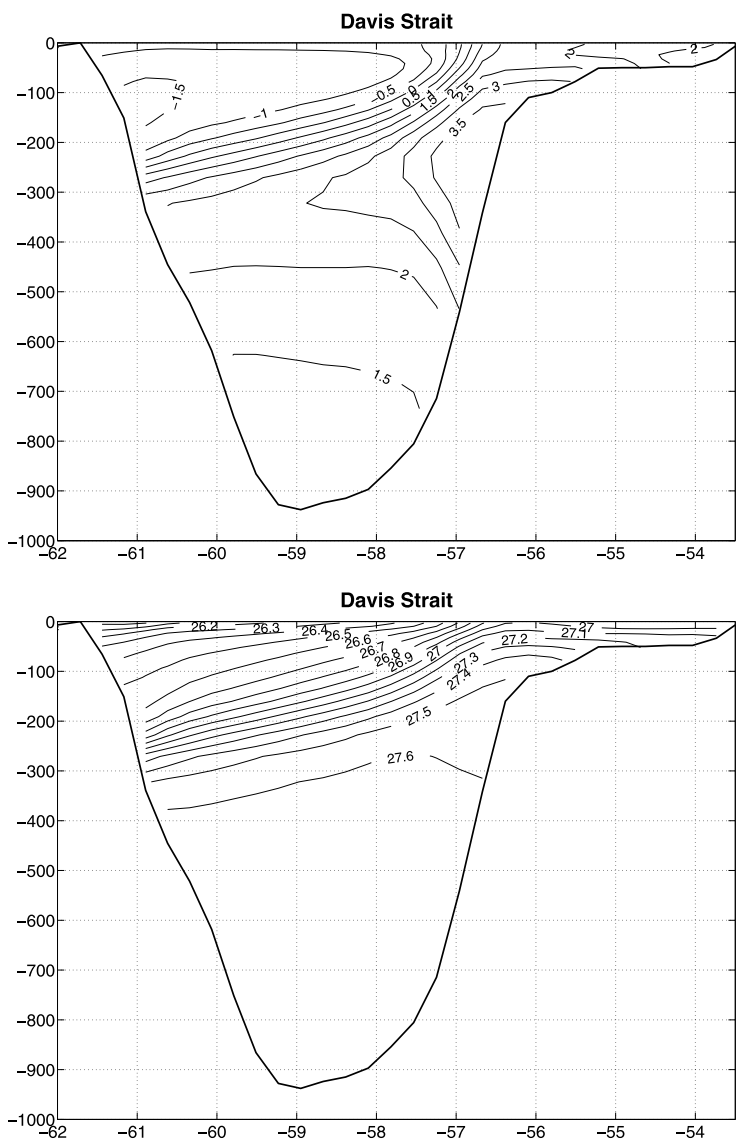

(b)
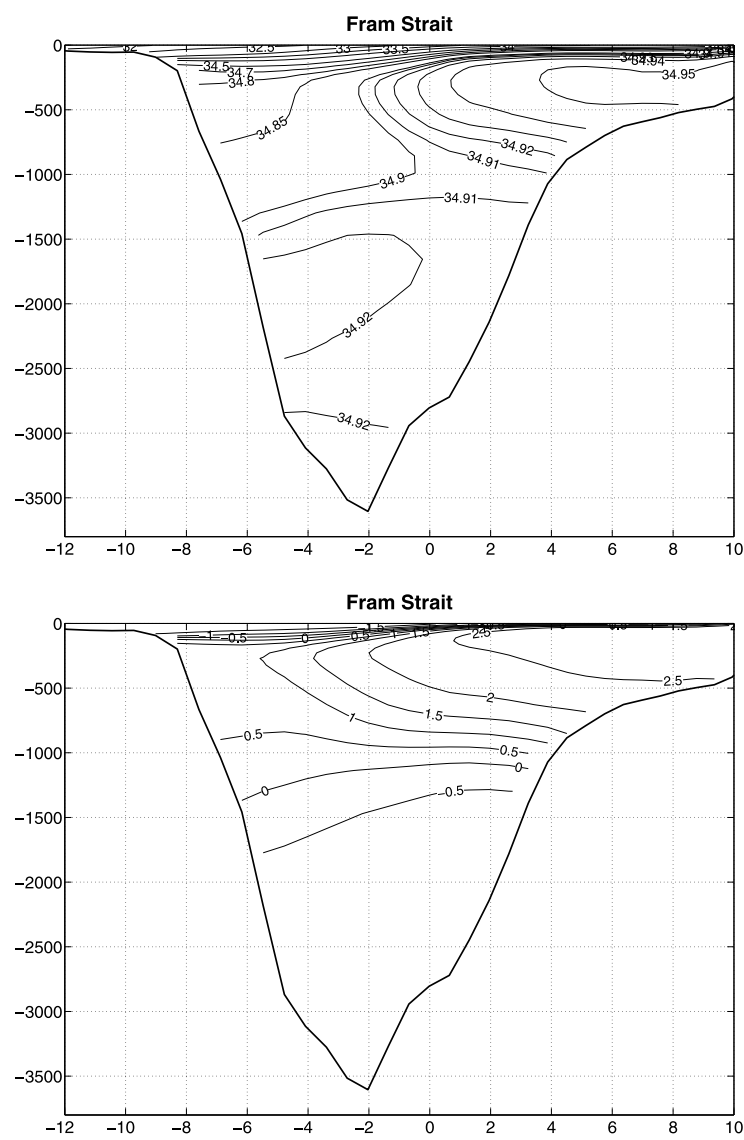

(d)

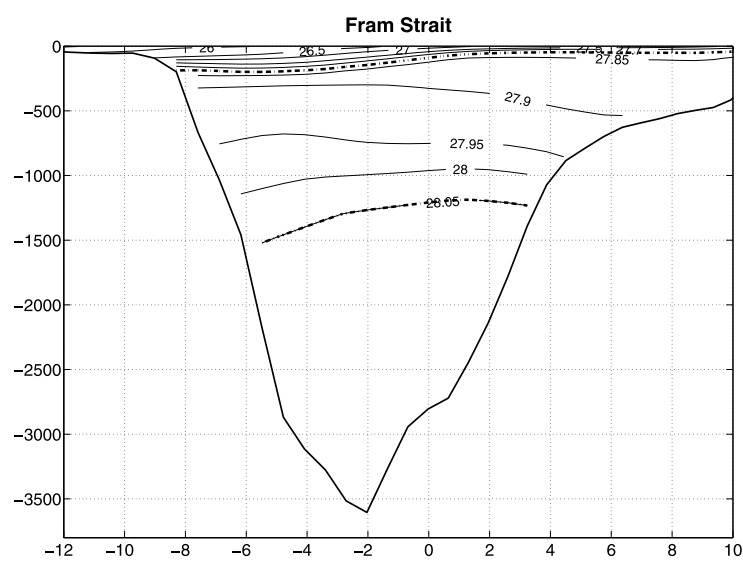

Figure 4. Model vertical section of (a and b) mean salinity (in psu), ( $c$ and d) mean temperature (in ${ }^{\circ} \mathrm{C}$ ), and (e and f) mean density (referenced to the surface) across Davis Strait (Figures $4 \mathrm{a}, 4 \mathrm{c}$, and $4 \mathrm{e}$ ) and Fram Strait (Figures $4 \mathrm{~b}, 4 \mathrm{~d}$, and $4 \mathrm{f}$ ). Isopycnal contours 27.8 and 28.05 are superimposed as dotted lines (Figure 4f).

\subsection{Origins of the Arctic Exports}

[25] Figure 5 and Table 2 show the different origins of the exports along both sides of Greenland and quantify their relative contributions.

\subsubsection{Davis Strait}

[26] At Davis Strait, the exports are composed of water masses originating from the four sections enclosing the Arctic Ocean. In the model, Pacific water from Bering Strait represents $36 \%$ of the total annual mean export, but this contribution becomes larger during summer and autumn. Proshutinsky et al. [2002] found that the strength of the Beaufort Gyre decreases during this period of the year, and thus an important amount of freshwater is released at that time. This seasonal cycle of the Beaufort Gyre intensity is well represented in the model, and, as in the model the transfer of Pacific water occurs through the Beaufort Gyre in the upper layers, the increase of Pacific water export through Davis Strait during summer and autumn is thus due to the increasing release of water by the gyre during these seasons. 

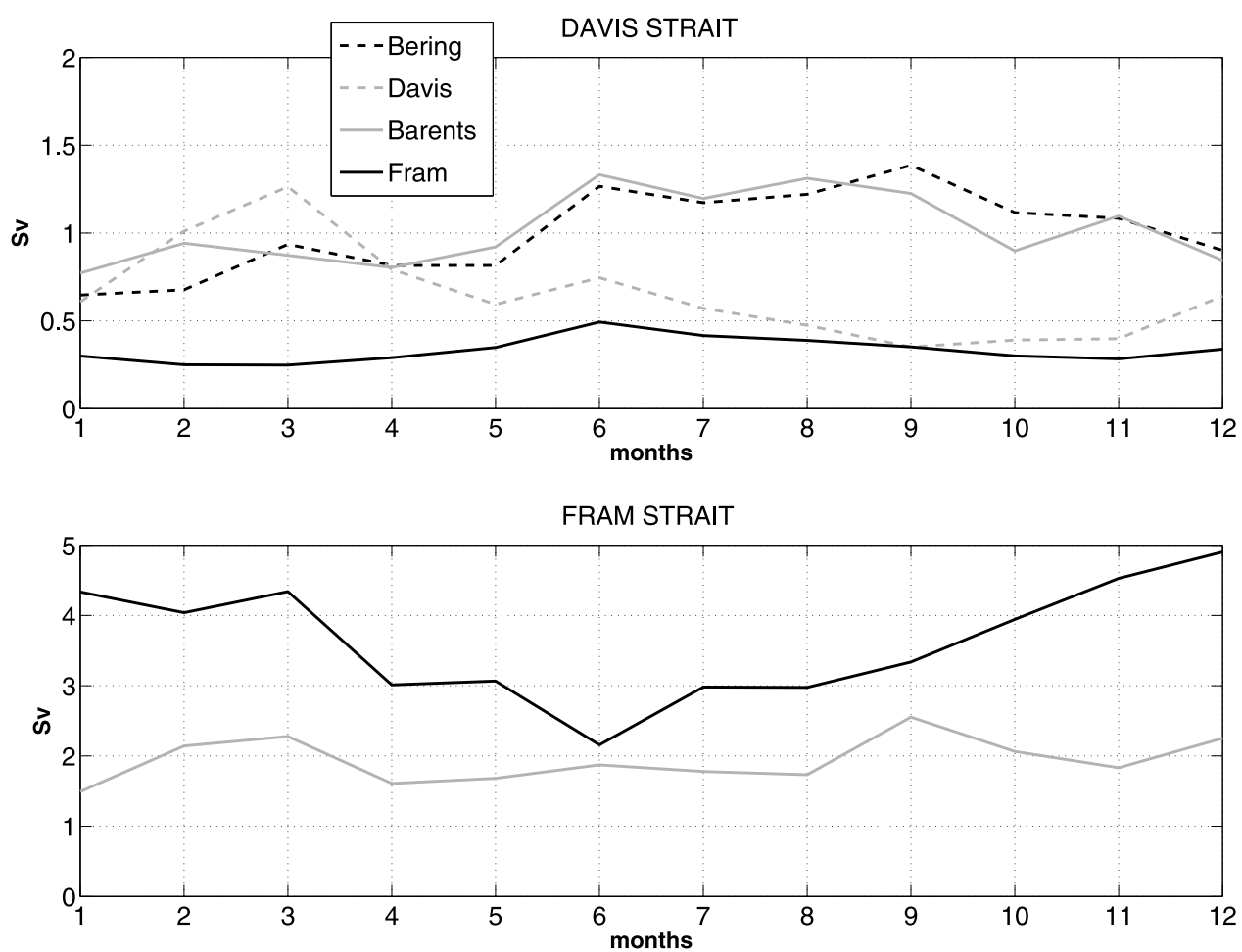

Figure 5. Monthly time series (in Sv) of the relative contributions accounting for the transport passing through (top) Davis Strait and (bottom) Fram Strait. The transport accounted for by the water masses that enter the Arctic through Bering Strait, Davis Strait, Fram Strait, and Barents Sea is drawn with a black dashed line, a gray dashed line, a solid black line, and a solid gray line, respectively.

[27] Almost 20\% of the export at Davis Strait enters the Arctic through this same section. It is however important to make the difference between the fraction of these waters that crosses the Baffin Bay and enters the Arctic further north, the fraction that just recirculates in the Baffin Bay, and the fraction that is caught in a short recirculation around the section. This will be discussed in the next section. Atlantic water entering the Arctic through Fram Strait or the Barents Sea represents a fraction of the exports (around 40\%) similar to that of the Pacific water, with a clear seasonal cycle as it increases during summer (especially the part originating in the Barents Sea).

\subsubsection{Fram Strait}

[28] In the model, almost all the water masses exported through Fram Strait are Atlantic water originating from Fram Strait or the Barents Sea. We only find small traces of Pacific water. The amount of Pacific water exiting through Fram Strait is too small compared to observations and estimates using dissolved nutrients [Jones et al., 1998, 2003; Taylor et al., 2003] and this model deficiency will be discussed in section 4.3.

[29] Waters exported near the surface or near the bottom are composed in equal part of water coming from Fram Strait and the Barents Sea. At the same time, the intermediate density class $\left(27.8 \leq \sigma_{0}<28.05\right)$ is mainly composed of waters entering the Arctic through Fram Strait (80\%). A seasonal cycle is clearly noticeable, as the export through Fram Strait increases during fall and winter. This is especially obvious for the water masses that recirculate from and to Fram Strait. This cycle is in opposition of phase with the transfer of Atlantic water to Davis Strait. The total amount of exported Atlantic water is thus roughly constant. This suggests spatial variability of the circulation rather than temporal variability.

\subsection{Streamlines, Circulation, and Residence Times}

[30] This part aims at diagnosing the pathways within the Arctic Ocean of the water that eventually exits along either sides of Greenland. The Lagrangian method allows visualization of streamfunctions obtained by vertical integration of the 3D transport field accounted for the particles displacement from an entrance to an exit section [Blanke et al., 1999]. Figures 6 and 7 show the streamfunctions of the transfers to Davis Strait and Fram Strait (in the three different layers), respectively. Figure 8 shows the accumulated transport at the exit sections (in percentages) as a function of time and for each possible pathway.

Table 2. Transport of the Different Branches That Contribute to the Southward Transport Through Davis Strait and Through Fram Strait in Three Different Density Layers ${ }^{\mathrm{a}}$

\begin{tabular}{lcccccc}
\hline & & \multicolumn{5}{c}{ Fram Strait } \\
\cline { 3 - 7 } & Davis Strait & $\sigma_{0}<27.8$ & $27.8 \leq \sigma_{0}<28.05$ & $\sigma_{0} \geq 28.05$ & Total \\
\hline Bering Strait & 1.11 & 0 & 0.01 & 0 & 0.01 \\
Davis Strait & 0.62 & 0 & 0 & 0 & 0 \\
Fram Strait & 0.36 & 0.65 & 2.14 & 0.92 & 3.71 \\
Barents Sea & 1.03 & 0.61 & 0.57 & 0.81 & 1.99 \\
Total & 3.12 & 1.26 & 2.72 & 1.73 & 5.71 \\
\hline
\end{tabular}

${ }^{\text {a }}$ Transport is given in Sv. Values smaller than $10^{-2}$ are set to 0 . 
(a)

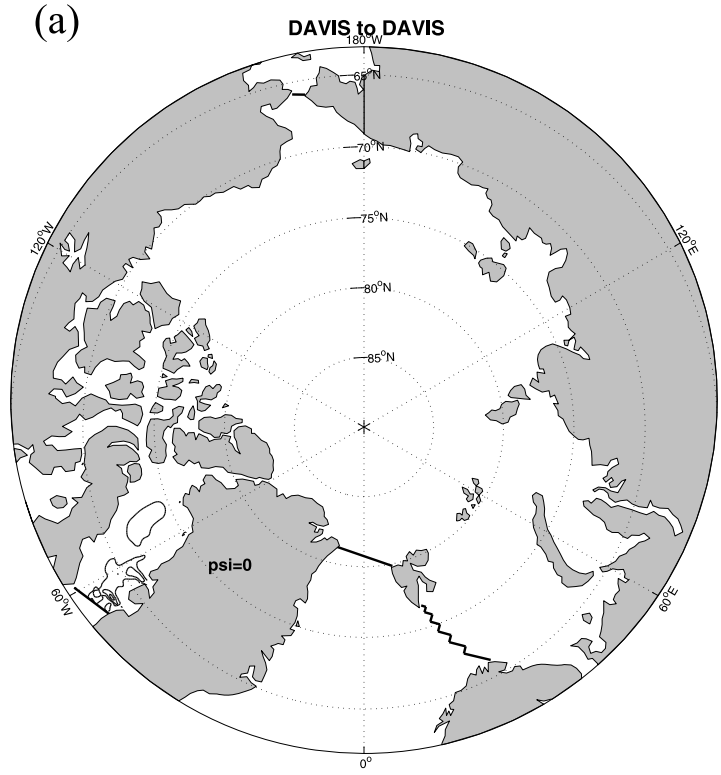

(c)

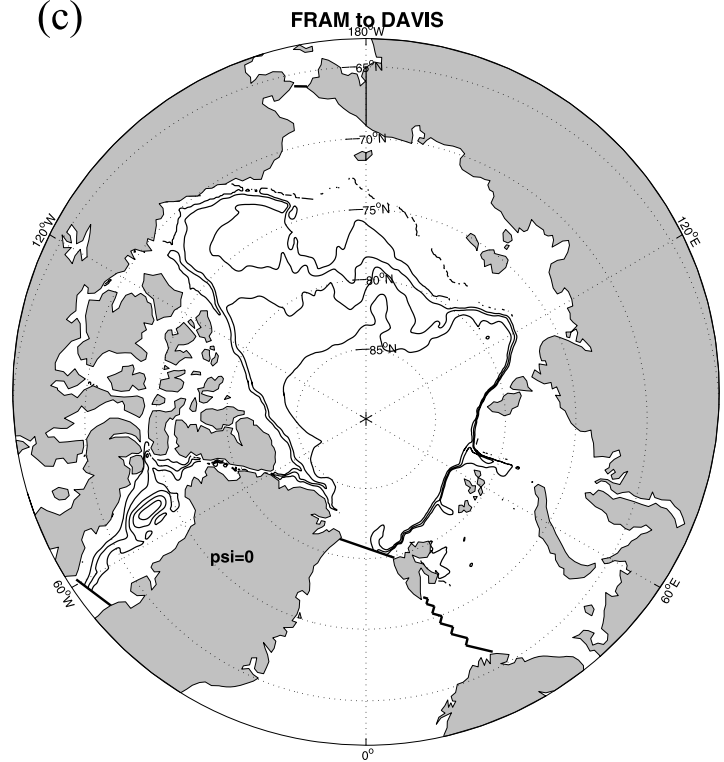

(b)

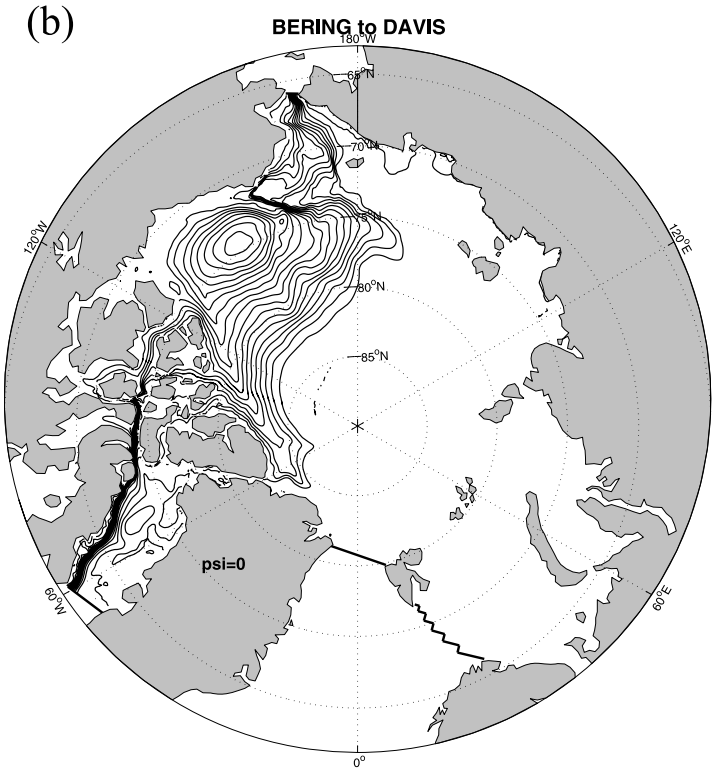

(d)

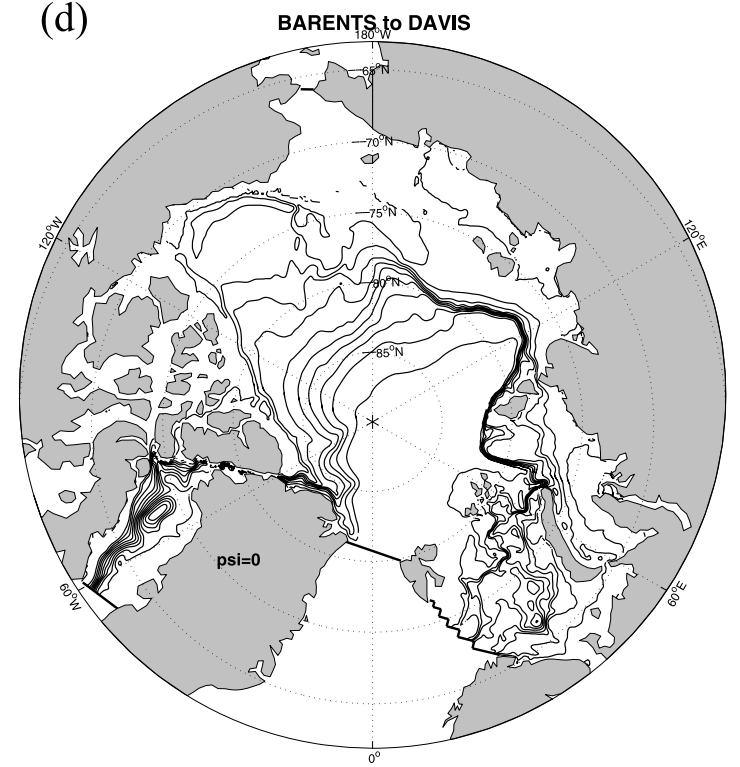

Figure 6. Horizontal mass stream function $\psi$ related to the vertically integrated transport of the water transfers to Davis Strait from (a) Davis Strait, (b) Bering Strait, (c) Fram Strait, and (d) Barents Sea. The contour interval is $0.1 \mathrm{~Sv}$ and $\psi$ is set to 0 over Greenland.

\subsubsection{Davis Strait}

[31] On their journey from the Pacific Ocean to the North Atlantic via Davis Strait, the water masses entering the Arctic through Bering Strait are swept into the anticyclonic Beaufort gyre. In the model, this transfer occurs completely in the upper layer of the Arctic (down to $300 \mathrm{~m}$ ), and the waters following this pathway remain in the Canadian Basin. This is consistent with the description of the lateral extent of the Pacific halocline presented by Steele et al. [2004], with an eastern limit being roughly the Mendeleyev Ridge. Figure 6 also shows that these waters mostly cross the CAA from M'Clure Strait to Lancaster Sound. One has to remember that the pathway through the CAA strongly depends on the model resolution, but these results are in good agreement with observations presented by Jones et al. [2003]. They report that "only pacific water appears to have exited from the Arctic Ocean through the CAA except via Nares Strait, where Atlantic water of Arctic origin (rather than having arrived from the south via the WGC) is encountered at depths of $75 \mathrm{~m}$ and greater". The transfer from Bering Strait to Davis Strait is fast (between 4 and 25 years), half of it being done in less than 8 years. This is coherent with the residence times for the upper Arctic Ocean calculated in previous studies using transient anthropogenic tracers: Ostlund and Hut [1984] estimated a range between 8 to 10 years and Schlosser et al. [1994] found a range between 9 to 20 years, with a general increasing trend of age with depth.

[32] Our Lagrangian analysis reveals that, in the model, the water that crosses Davis Strait northward within the West Greenland Current (WGC) is not entering the Arctic Ocean. It recirculates within Baffin Bay, and exits quickly 


\section{(A) SURFACE LAYER}
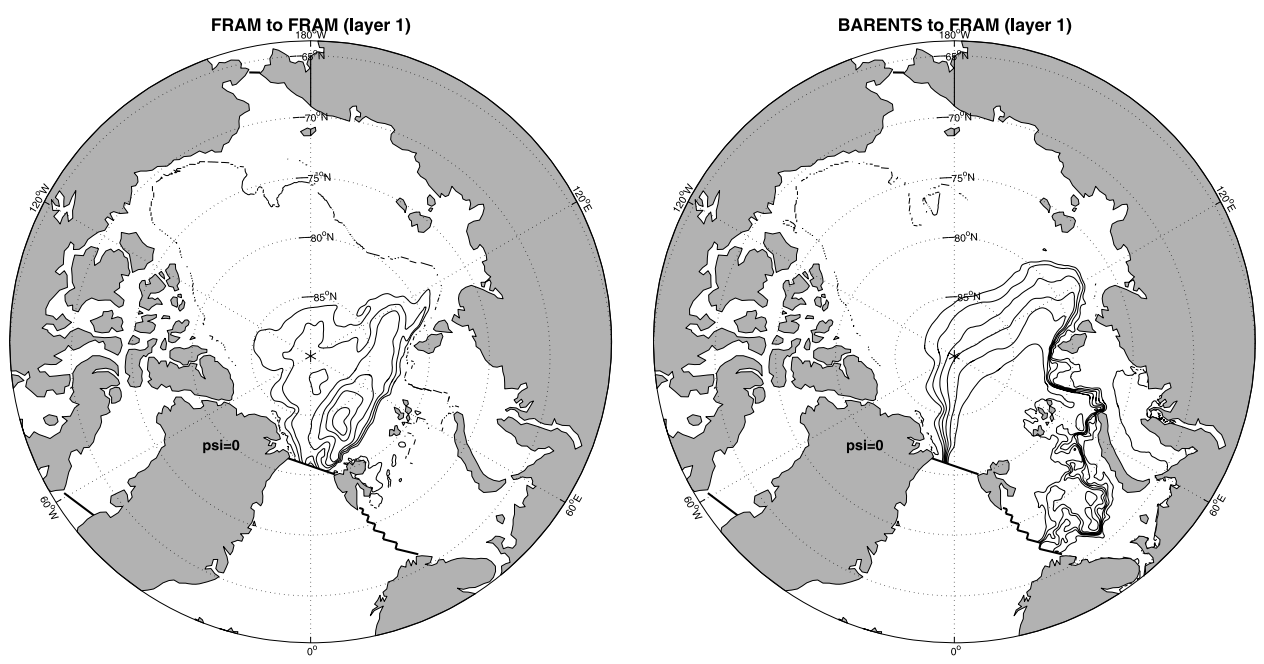

(B) INTERMEDIATE LAYER
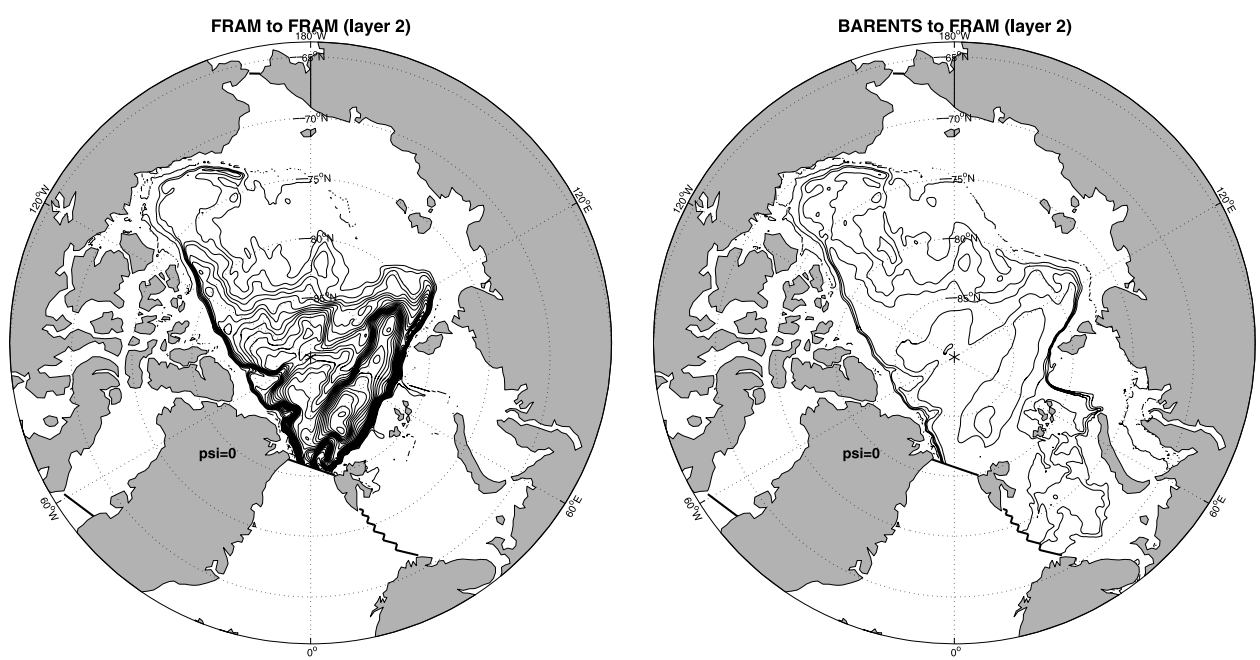

(C) DEEP LAYER
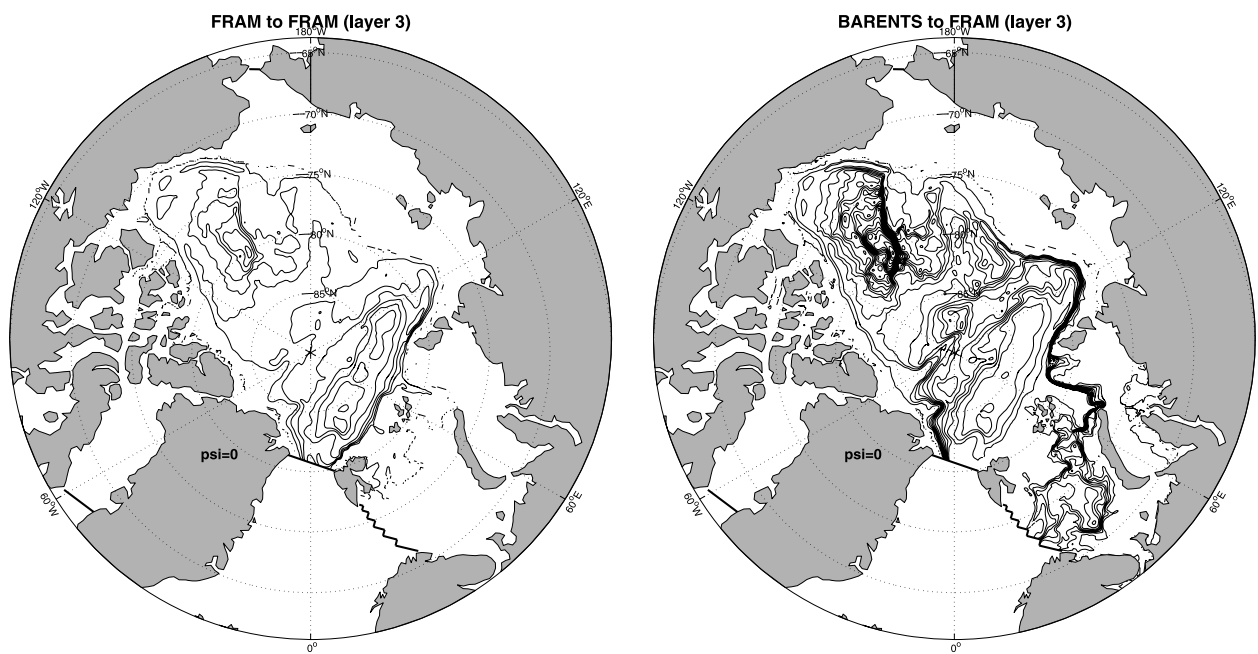

Figure 7. Horizontal mass stream function $(\psi)$ related to the vertically integrated transport of the water transfers to three different layers in Fram Strait from (left) Fram Strait and (right) Barents Sea. The contour interval is $0.1 \mathrm{~Sv}$ and $\psi$ is set to 0 over Greenland. 

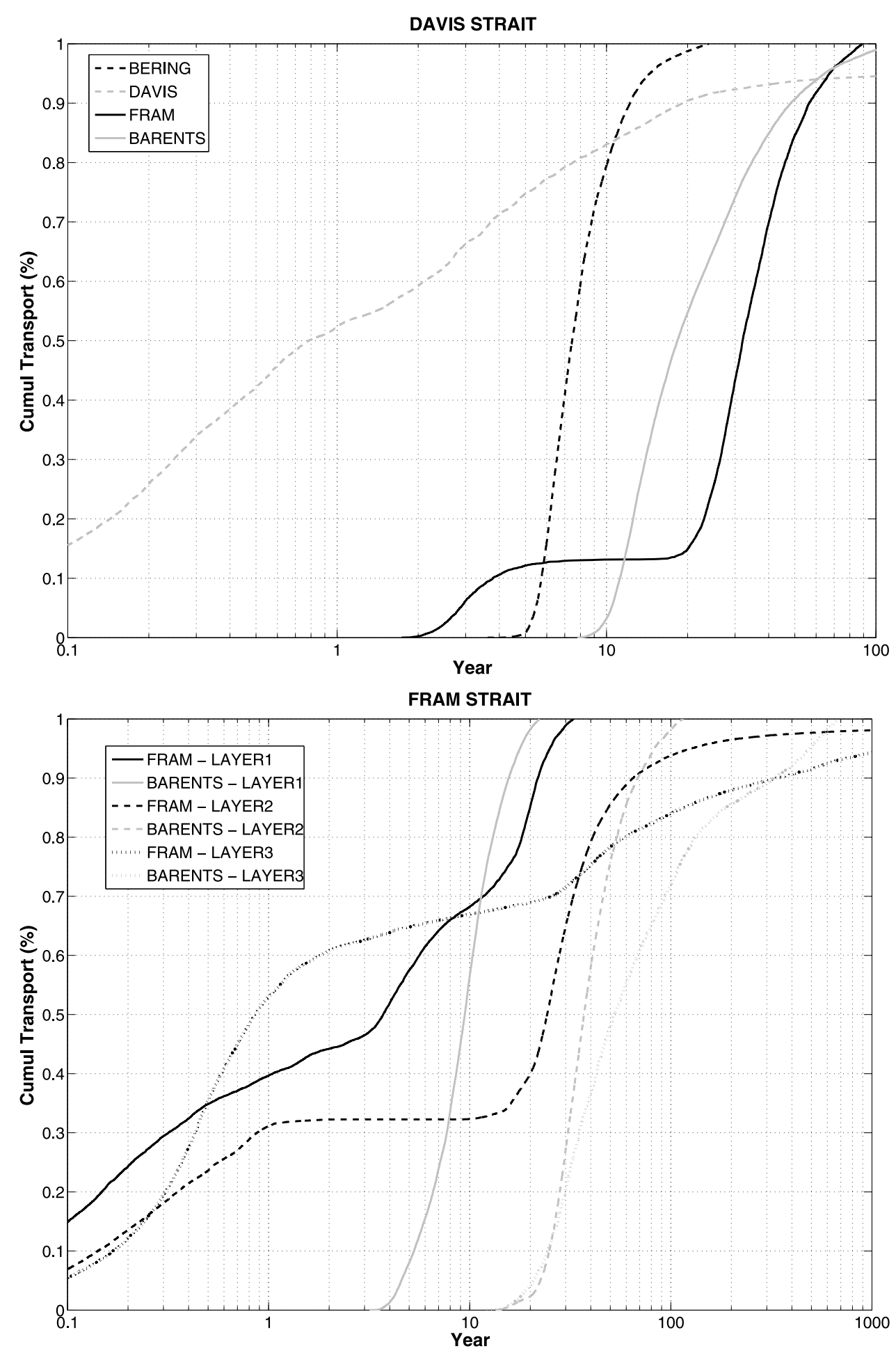

Figure 8. Normalized time-integrated transport as a function of travel times for the different connections under consideration. (top) To Davis Strait from Bering Strait, Davis Strait, Fram Strait, and Barents Sea with a black dashed line, a gray dashed line, a solid black line, and a solid gray line, respectively. (bottom) To Fram Strait from Fram Strait and Barents Sea with a black line and a gray line, respectively. Individual layers are shown with different line styles.)

southward through Davis Strait (half of the transfer is done in less than 10 months). The streamlines follow the isobaths, suggesting that the recirculation is subject to topographic constraints.
[33] We now focus on the part of the export at Davis Strait that is composed of Atlantic water entering the Arctic through Fram Strait or the Barents Sea. Streamlines that represent the transfer from Fram Strait to Davis Strait follow 
roughly the isobaths. In the model, water masses follow the Nansen Basin slope, and enter to the northern part of the Laptev Sea. Then a branching occurs: one branch flows down along the Lomonosov Ridge in the Makarov Basin, whilst the other branch enters the Canadian Basin and joins the Beaufort Gyre. To get to Davis Strait, Atlantic water crosses the CAA mostly trough Nares Strait and then Smith Sound, which is also consistent with Jones et al. [2003]. The whole transfer occurs mainly in the surface and intermediate layers (down to $400 \mathrm{~m}$ ) and travel times are between 20 and 90 years.

[34] A similar circulation scheme is found for waters entering through the Barents Sea. It first recirculates in the Barents Sea and then follows the same pathways. A part of these waters travels faster, as the first particles inseminated in the Barents Sea reach Davis Strait 8 years later, and 50\% of the transfer occurs in less than 17 years. Transit times are consistent with the times scale related to the circulation scheme proposed by Smethie et al. [2000], in which waters entering the Barents Sea reach the North of Greenland about 23 years later.

[35] Concerning the Atlantic water pathways, Nazarenko et al. [1998] use a passive tracer integration in their model and find a more direct and intense return flow along the Amundsen side of the Lomonosov Ridge, a process that our model fails to reproduce. Nazarenko et al. [1998] use an eddy parametrization (the so-called Neptune effect) and show that the eddy-topography interactions are important to properly reproduce this branch of the circulation. As we do not use such a parametrization in our model and as our resolution is too coarse to resolve eddies in the Arctic, our global model may underestimate this branch of circulation for the Atlantic water.

\subsubsection{Atlantic Water Exiting Through Fram Strait}

[36] In the model, most of the water flowing northward within the North Atlantic Drift Current exits the Arctic Ocean through Fram Strait. The circulation scheme and related times scale are strongly dependent on the density classes considered. The water masses that form the surface layer of the export are making a short travel in the Arctic Ocean, both for time and distance. They stay in the Nansen Basin and flow southward within the Transpolar Drift to Fram Strait. These waters need less than 30 years to leave the Arctic, half of the transfer being done in 4-9 years, depending on whether they enter through Fram Strait or Barents Sea.

[37] The intermediate waters that exit through Fram Strait are originating from Fram Strait $(80 \%)$ and the Barents Sea $(20 \%)$. Figure $7 \mathrm{~b}$ shows three structures corresponding to the different possible pathways. A part of the water stays in the Nansen Basin, and then flows southward along the Lomonosov Ridge with the transpolar drift before it exits through Fram Strait (this returning flow along the ridge is probably underestimated in the model as explained in the previous paragraph). The remaining water masses cross the Lomonosov Ridge. One branch flows around the Makarov Basin along the East Siberian Sea slope and the Alpha/ Mendeleyev Ridge, whilst a second branch enters the Canadian Basin and follows the other side of the Alpha/ Mendeleyev Ridge. These latter two branches of circulation converge to the north of the CAA and follow the continental slope until they leave the Arctic through Fram Strait. This circulation scheme for the intermediate water is fully consistent with the one predicted by Rudels et al. [1994] and also described by Smethie et al. [2000]: the scheme consists of three large cyclonic cells in the three different basins. Half of the transfer from Fram Strait to Fram Strait is done in less than 25 years in the model, even though part of the water can remain more than 1000 years in the basin. The first plateau for this transfer visible in Figure 8 corresponds to the part of the water that just recirculates near the strait. The particles that follow the pathway from the Barents Sea to Fram Strait need 10 to 100 years to exit, half of them exiting after 40 years. The time scales obtained for intermediate Atlantic water are similar to the ones usually found in the literature, with an order of magnitude around 20 years [Schlosser et al., 1995; Smethie et al., 2000; Karcher and Oberhuber, 2002].

[38] The deep layer $\left(\sigma_{0} \geq 28.05\right)$ of the export through Fram Strait is roughly composed in equal part of water entering the Arctic through Fram Strait and through the Barents Sea. Figure 7c shows that the circulation schemes for both transfers are similar, and also similar to the pathway followed by the waters exiting in the intermediate layer. However, half of the water coming from Fram Strait exits the Arctic after 11 months, whereas this time increases to 50 years for the water flowing from the Barents Sea. The time scales related to the pathway from the Barents Sea to Fram Strait are consistent with the study of Ostlund et al. [1987] in which the renewal time for the deep water by the Barents Sea Branch is estimated around 100 years.

\subsection{Lack of Pacific Water at Fram Strait: A Model Deficiency?}

[39] Our Lagrangian analysis shows that, in the model, almost all the Pacific water entering the Arctic through Bering Strait exits through the CAA and then Davis Strait, whilst we can only find small traces of Pacific water at Fram Strait. However, many recent studies [Jones et al., 1998, 2003; Taylor et al., 2003; Falck et al., 2005] used concentrations of dissolved nutrients to trace Pacific water into the North Atlantic, and showed that a substantial fraction of Pacific water exits on the eastern side of Greenland, through Fram Strait. As our study aims at determining the origins of the exports along both sides of Greenland, it is crucial to analyze the model deficiency and to quantify its impact on our results.

[40] Jones et al. [1998] used nitrate and phosphate concentration relationships to distinguish Atlantic from Pacific waters and estimated their relative amounts in the first $30 \mathrm{~m}$ in the Arctic Ocean. They showed that Pacific water exits the Arctic in the western part of Fram Strait within this layer. Afterward, Jones et al. [2003] used the same method to show that the exports done in the first $100 \mathrm{~m}$ and within $100 \mathrm{~km}$ of the Greenland coast at Fram Strait were mainly composed of Pacific water between 1997 and 1999, even though interannual variability can lead to large changes in the amount of Pacific water [Taylor et al., 2003], with complete disappearance of the strongest part of the signal (above the shelf and slope northeast of Greenland) in some years [Falck et al., 2005]. Note that in our model, the area across the Fram Strait section where Pacific water should be found is small relative to the area covered by the outflowing branch. If the same is true in the real ocean, it implies that, 
Table 3. Freshwater and Heat Transports at the Entrance and Exit Sections for the Different Possible Pathways ${ }^{\mathrm{a}}$

\begin{tabular}{|c|c|c|}
\hline Pathway & Entrance & Exit \\
\hline \multicolumn{3}{|l|}{ Bering to Davis } \\
\hline Freshwater transport (mSv) & 81.2 & 51.6 \\
\hline Heat transport (TW) & 5.0 & -3.2 \\
\hline \multicolumn{3}{|l|}{ Fram to Davis } \\
\hline Freshwater transport (mSv) & 1.1 & 11.4 \\
\hline Heat transport (TW) & 3.4 & 0.2 \\
\hline \multicolumn{3}{|l|}{ Barents to Davis } \\
\hline Freshwater transport (mSv) & -1.9 & 42.7 \\
\hline Heat transport (TW) & 21.5 & -1.9 \\
\hline \multicolumn{3}{|l|}{ Fram to Fram } \\
\hline \multicolumn{3}{|l|}{ Freshwater transport (mSv) } \\
\hline Layer 1 & 0.5 & 16.9 \\
\hline Layer 2 & -8.6 & -3.7 \\
\hline Layer 3 & -3.3 & -3.0 \\
\hline \multicolumn{3}{|l|}{ Heat transport (TW) } \\
\hline Layer 1 & 6.8 & -0.6 \\
\hline Layer 2 & 20.0 & 9.5 \\
\hline Layer 3 & 1.6 & -1.2 \\
\hline \multicolumn{3}{|l|}{ Barents to Fram } \\
\hline \multicolumn{3}{|l|}{ Freshwater transport (mSv) } \\
\hline Layer 1 & -1.4 & 31.5 \\
\hline Layer 2 & -1.5 & -0.9 \\
\hline Layer 3 & -2.2 & -2.5 \\
\hline \multicolumn{3}{|l|}{ Heat transport (TW) } \\
\hline Layer 1 & 12.8 & -2.8 \\
\hline Layer 2 & 10.9 & 1.6 \\
\hline Layer 3 & 15.5 & -0.3 \\
\hline
\end{tabular}

${ }^{\mathrm{a}}$ The first strait or sea given is the entrance and the second strait or sea given is the exit. Two secondary pathways("Davis to Davis" and "Barents to Barents") are deliberately omitted.

in term of transport, the contribution of this water mass remains quite small compared to the Atlantic water contribution, even though the Pacific water probably contributes significantly to the freshwater export.

[41] What could be, in our model or in our methodology, the explanation for the lack of Pacific water? First, the Lagrangian analysis has been run over a climatological year built over monthly mean model outputs from 1980 to 2001 . This mean state of the Arctic might not be representative of any instantaneous state of the Arctic dynamics. We have run a sensitivity Lagrangian experiment, using 5 years made of successive 5 day model outputs, to calculate forward trajectories of particles inseminated at Bering Strait. We repeated those 5 years until the slowest particle exited the domain of integration. The transport transmitted to Fram Strait is still negligible ( 0.02 vs 0.01 in Table 2$)$, the transport to Davis is similar (1.07 vs $1.11 \mathrm{~Sv}$ in Table 2, with half of the particles exiting in less than 8 years with an age distribution similar to Figure 8 ). It is not possible to redo all our calculations with the 5 day outputs for practical (prohibitive computer time requirements) as well as methodological reasons (looping over a given time period to compute long trajectories is questionable). Nevertheless, this single sensitivity experiment suggests that the lack of Pacific water at Fram Strait is not an artifact of the Lagrangian method but rather a shortcoming of the Eulerian fields.

[42] A second explanation could be the fact that in the model all the simulated Pacific water is swept into the Beaufort Gyre. Figure 6 shows that the simulated Pacific water is completely transferred to the North Atlantic through the Beaufort Gyre. Steele et al. [2004] used observations of the halocline in the Arctic and showed that some Pacific water enters the Arctic within a coastal current on the eastern side of Bering Strait, and continues along the shelf break, as also previously suggested by Jones et al. [1998]. As mentioned by Lique et al. [2009], our simulated Beaufort Gyre is probably displaced too close to the Canadian coast compared to its observed location, and the coastal current along the shelf is not properly simulated. This model deficiency might be due to a too coarse spatial resolution, or the underestimation of eddy-topography interactions that would help to simulate the coastal current following the shelf north of the CAA [Nazarenko et al., 1998]. It can also been seen in the study of Holloway and Wang [2009] where simulation with a coarse model but with a parametrization of the Neptune effect simulates properly a narrow current on the shelf along the Canadian Coast.

[43] Third, the model grid (12 km) is too coarse to resolve most of the mesoscale activity. Spall et al. [2008] highlight the presence of eddies along the southern Beaufort Sea, and show their ability to transport Pacific water properties to the interior of the basin. This suggests that a fraction of the Pacific water entering the Arctic through Bering Strait could be transported via eddies with typical diameters of $30 \mathrm{~km}$. We can logically infer that if a part of the transfer of Pacific water to Fram Strait occurs in such eddies, it is not represented in our Lagrangian trajectories but rather appears as a transformation of the Atlantic branch due to the model isopycnal diffusion.

\section{Water Mass Transformations in the Arctic Ocean}

\subsection{Pacific Water}

[44] Modification of Pacific water in the Arctic Ocean is a key point for the freshwater storage and release in the Arctic Ocean [Häkkinen and Proshutinsky, 2004]. Its quantification as well as the mechanisms at play are the focus of this section.

[45] In order to quantify the modifications, we compute the freshwater and heat fluxes corresponding to the different water masses at their entrance and exit sections in the Arctic. The freshwater flux is computed as

$$
T_{F W}=\sum_{\text {part }} \frac{S_{0}-S_{\text {part }}}{S_{0}} \operatorname{Tr}_{\text {part }},
$$

where $S_{0}$ is a reference salinity, here equal to $34.8 \mathrm{psu}$ to be consistent with the estimations given in section $3, S_{\text {part }}$ is the salinity of each particle at the entrance (or exit) section and $T r_{\text {part }}$ is the infinitesimal transport associated with the same particle. The heat flux is defined in an equivalent way as

$$
T_{H}=\sum_{\text {part }} \rho_{0} C_{p}\left(T_{\text {part }}-T_{0}\right) T r_{\text {part }}
$$

$T_{\text {part }}$ being the temperature of a given particle at the entrance (or exit) section and $T_{0}$ a reference temperature chosen as $-0.1^{\circ} \mathrm{C}$ to be consistent with results given in section 3 .

[46] Results for the pathway from Bering Strait to Davis Strait are given in Table 3. A comparison with the values given in Table 1 shows that, in our simulation, the outflow of Pacific water through Davis Strait accounts for $40 \%$ of the total freshwater export and $100 \%$ of the total heat export 

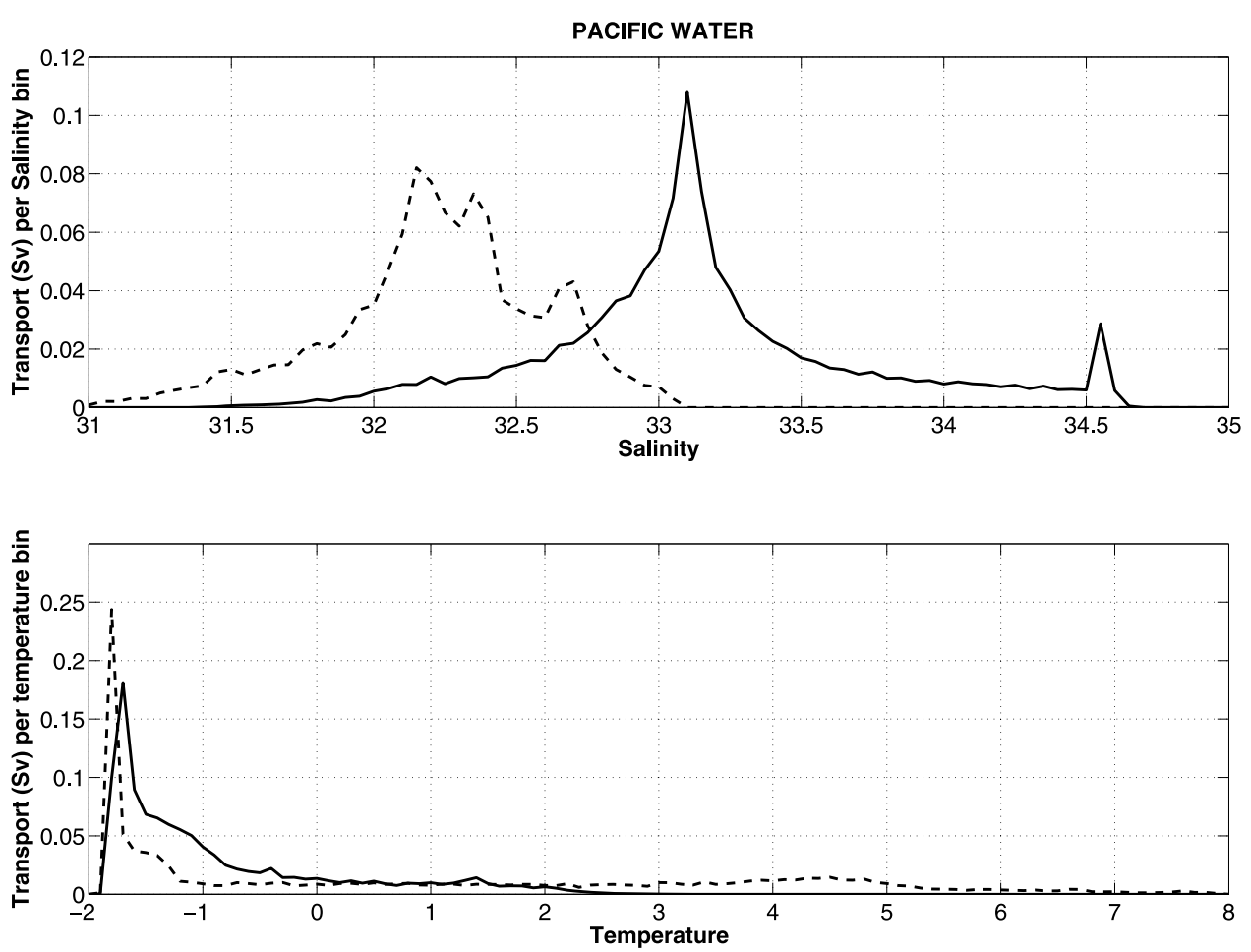

Figure 9. (top) Transport binned as a function of salinity at the entrance and exit sections for the Pacific water. The bin interval is 0.05 psu. (bottom) Same as Figure 9 (top) but as a function of temperature. The bin interval is $0.1^{\circ} \mathrm{C}$.

through this exit. Pacific water is the most important advective source of freshwater for the Arctic Ocean. Figure 9 shows the transport distribution binned into salinity and temperature classes at the entrance and exit sections for this water mass. During its travel into the Arctic Basin, Pacific water becomes saltier, while its temperature only slightly warms. This water mass is thus contributing to a freshening and a cooling of the Arctic Ocean. As the Pacific water is transferred in the surface layer, one has to remember that the quantification of this water mass transformation is affected by the strong restoring used in the simulation, which results in a large surface flux correction as shown by Lique et al. [2009].

[47] Figures 10a and 10b suggests that Pacific water does not cross any temperature or salinity front before being swept in the Beaufort Gyre. In the model, the limit of the sea ice extent moves seasonally in the Beaufort Sea. The yearly mean sea ice extent as well the September and March mean sea ice extent seem to be consistent with observations (Figures 10e and 10f). However, when we follow the T/S properties of Pacific water along its pathway, the limit of sea ice extent does not correspond to any important and abrupt water mass transformation. It thus suggests that modifications of Pacific water are done gradually along its travel in the Arctic by turbulent mixing with the water masses already present in the Beaufort Gyre.

\subsection{Atlantic Water}

\subsubsection{Quantification of the Water Mass Transformations}

[48] Atlantic water exiting the Arctic through Davis Strait or within the upper layer in Fram Strait undergoes strong freshening and cooling in the Arctic Basin. Its T/S properties are qualitatively similar at the entrance and exit sections for the Fram Strait Branch and the Barents Sea Branch (Figure 11, Davis Strait and layer 1). However, the Barents Sea Branch is saltier as it exits through Davis Strait than through Fram Strait. The part of Fram Strait Branch that eventually exits through Davis Strait is colder at the entrance section than the part exiting through Fram Strait. Thus, the Barents Sea Branch undergoes stronger modifications than the Fram Strait Branch. This is also shown by freshwater and heat fluxes calculated at the entrance and exit sections (Table 3). As its upper layer salinity and temperature decrease during the transit, the Atlantic water carries more freshwater and less heat, and thus contributes to a salinification and a warming of the Arctic Ocean. From its entrance in the Arctic to its exit trough Davis Strait or through the upper part of Fram Strait, the Barents Sea Branch gains around $80 \mathrm{mSv}$ of freshwater and loses around $40 \mathrm{TW}$ of heat. The figures are only about $25 \mathrm{mSv}$ and $10 \mathrm{TW}$ for the Fram Strait Branch.

[49] The picture is different for the water masses exiting within the intermediate and deep layers through Fram Strait (Figure 11, layers 2 and 3). During its transit within the Arctic Basin, Atlantic water undergoes a slight modification of salinity whilst its temperature strongly decreases. For water masses exiting in the intermediate density class, salinity decreases from 34.9 to 34.8 psu whilst the peak of temperature goes from $4^{\circ} \mathrm{C}$ to $0.2^{\circ} \mathrm{C}$ for the Barents Sea Branch and from $2{ }^{\circ} \mathrm{C}$ to $0.8^{\circ} \mathrm{C}$ for the Fram Strait Branch. Modifications of the water masses composing this layer thus contribute to a salinification and a significant warming of the Arctic Ocean, mainly due to modifications of the Fram 

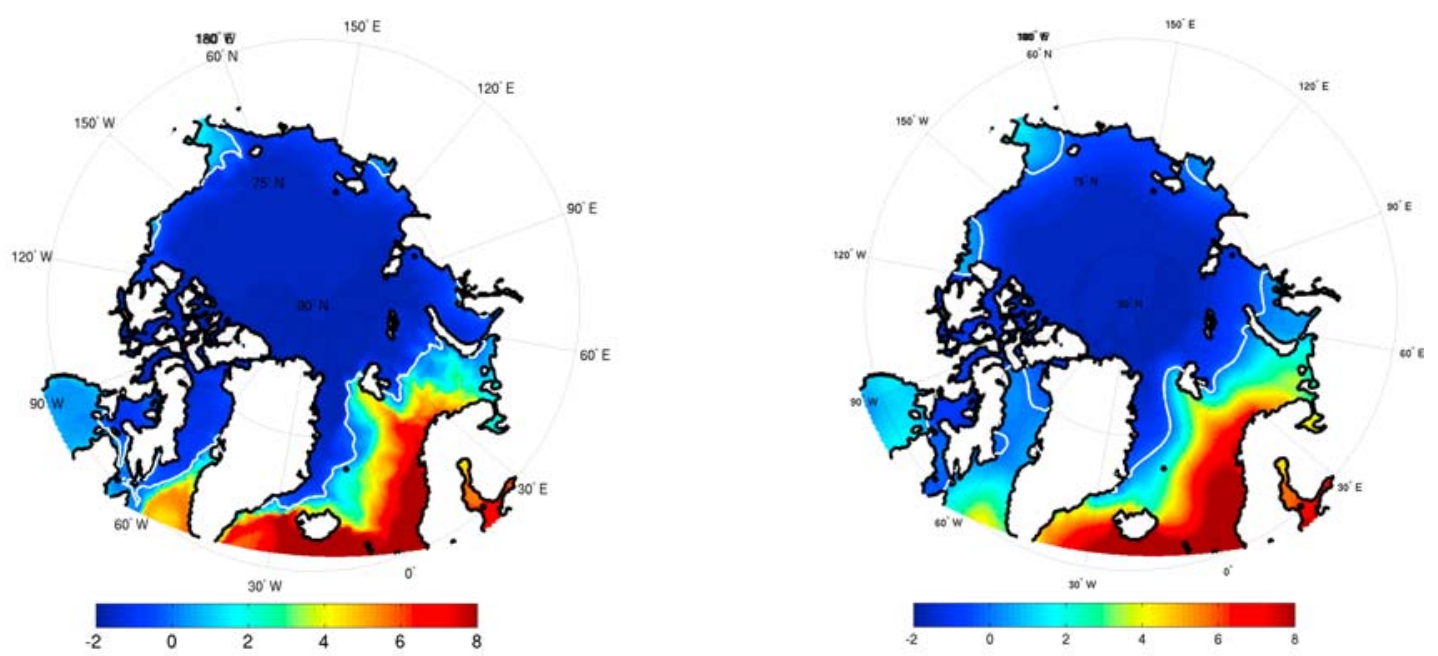

(a)

(b)
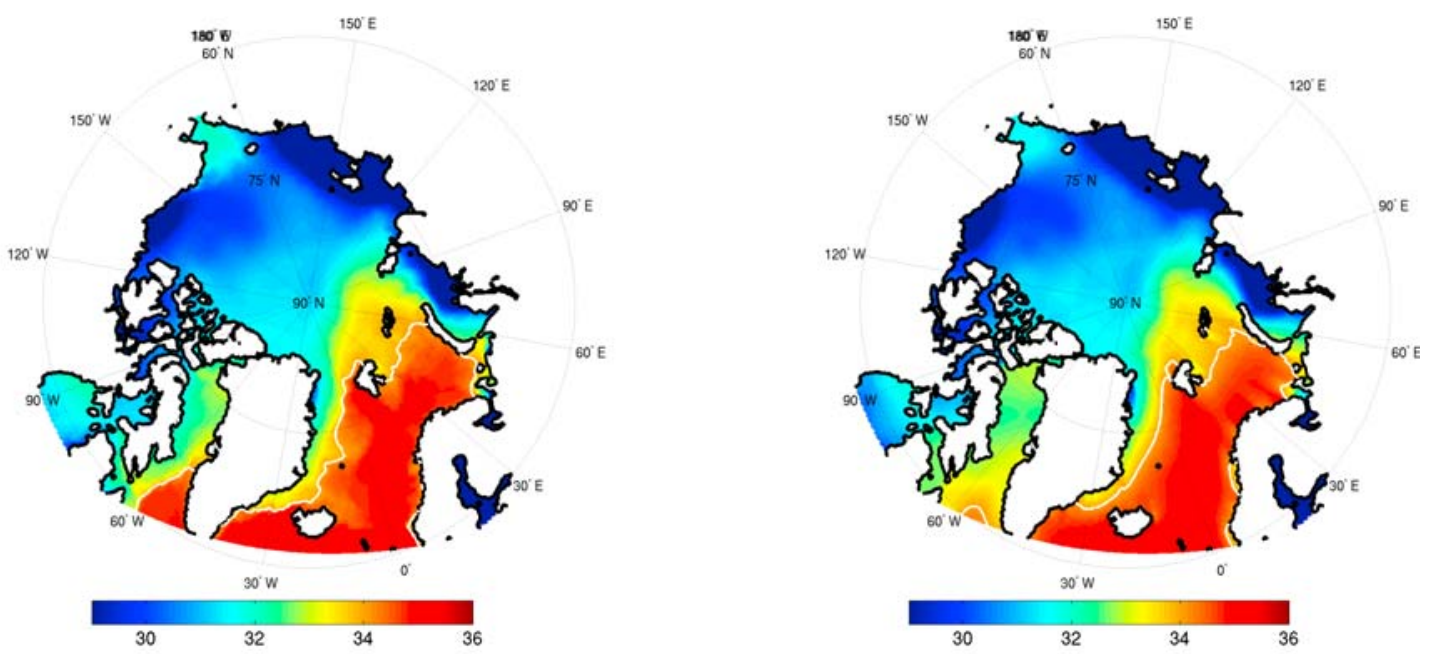

(c)

(d)
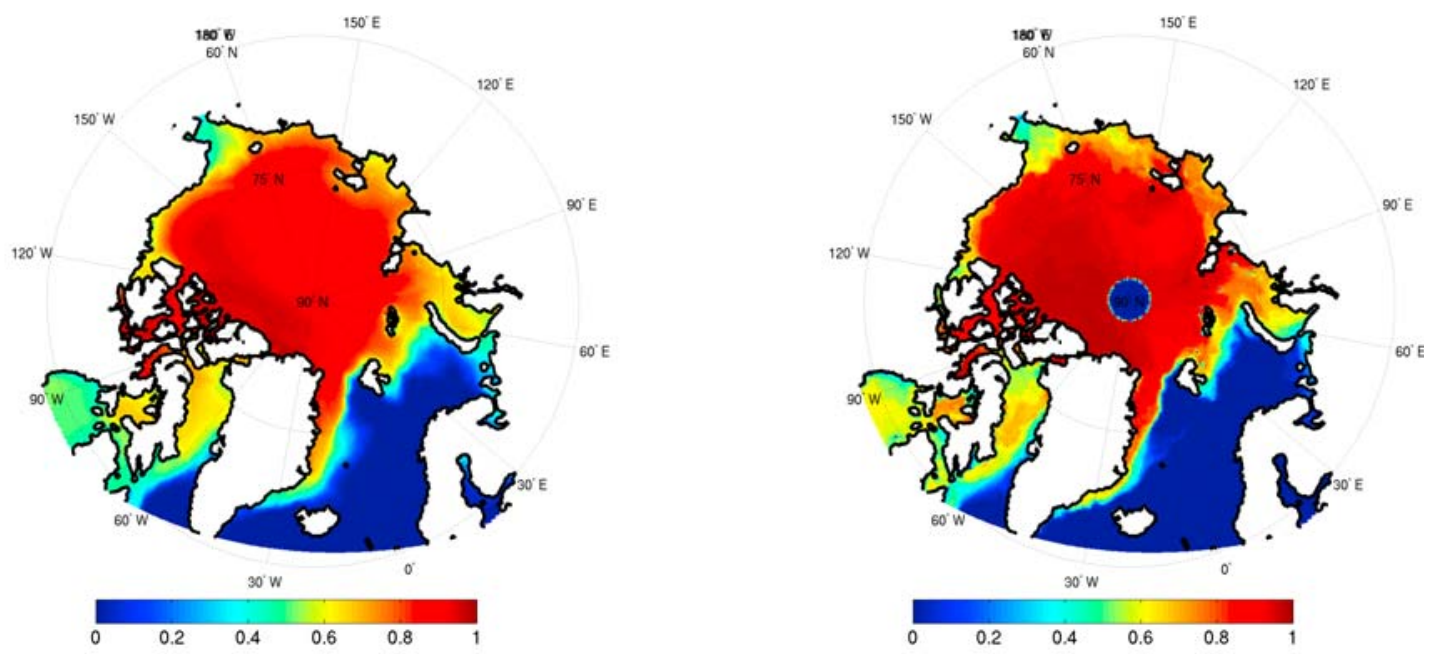

(e)

(f)

Figure 10. Mean model fields over the Arctic Ocean. (a) Sea surface temperature is given in ${ }^{\circ} \mathrm{C}$. The $0^{\circ} \mathrm{C}$ contour is superimposed in white. (c) Sea surface salinity is given in psu. The 34 psu contour is superimposed in white. (e) Sea ice concentration. Same as Figures 10a, 10c, and 10e but for the (b and d) PHC climatology and (f) sea ice observations averaged over 1992-2001 [Ezraty et al., 2007]. 

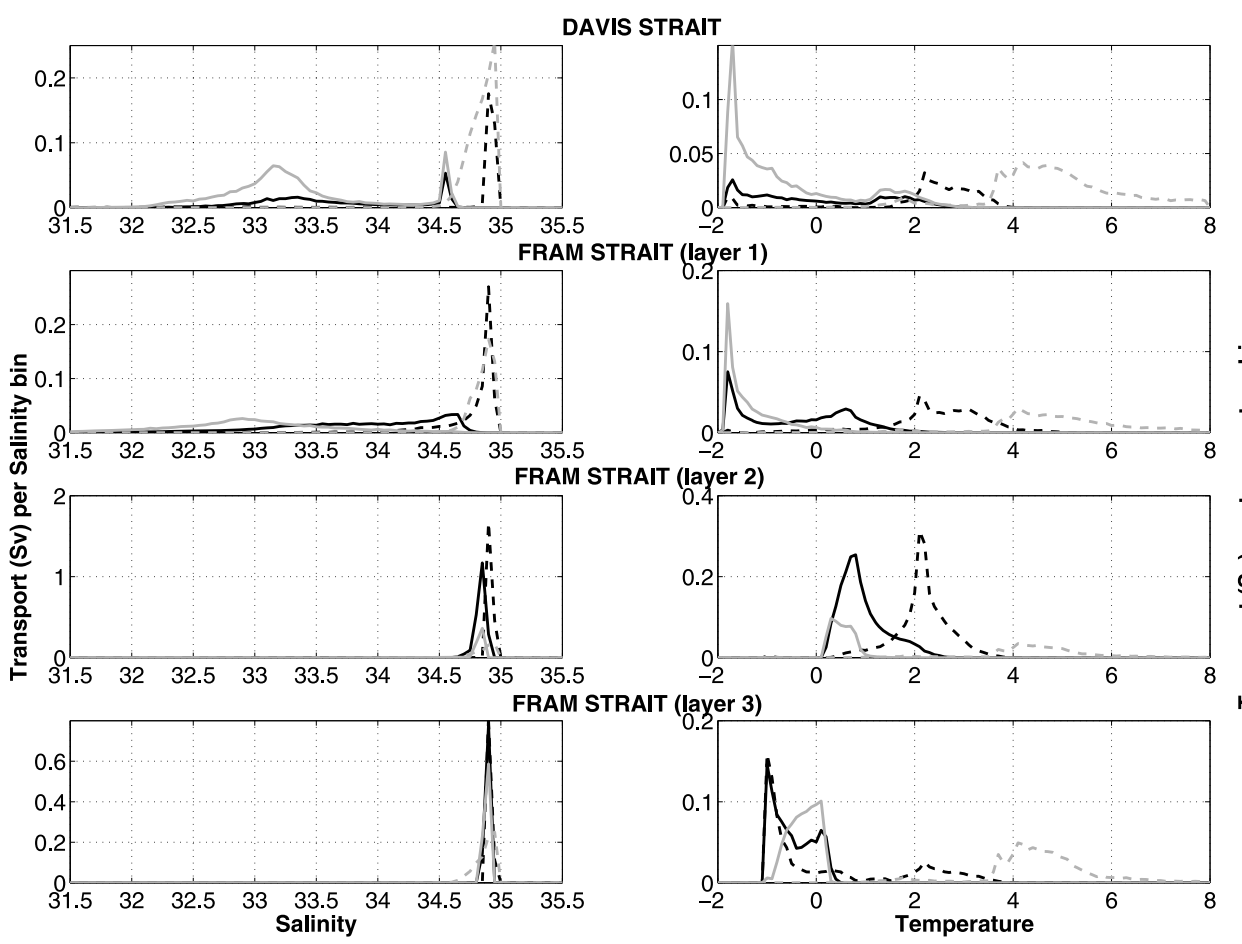

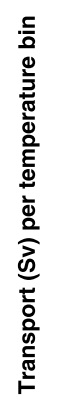

Figure 11. (left) Transport binned as a function of salinity at the entrance and exit sections for the Atlantic water. The bin interval is 0.05 psu. (right) Same as Figure 11 (left) but as a function of temperature. The bin interval is $0.1^{\circ} \mathrm{C}$. The Barents Sea Branch is given in gray, and the Fram Strait Branch is given in black. Distributions on entrance and exit sections are shown as dashed and solid lines, respectively.

Strait Branch (see Table 3). In the deeper layer, the Fram Strait Branch undergoes a slight freshening and cooling, whilst the Barents Sea Branch undergoes a slight salinification, together with an important cooling.

[50] To summarize the Atlantic water modifications, the Atlantic water undergoes a general cooling and a freshening during its transit in the Arctic Ocean. One must not forget, however, that all the figures given in this section might be strongly model dependent, especially because of the surface salinity restoring used in the simulation. Atlantic water transformations represent a gain of salt and heat for the Arctic Ocean, but the gain does not come from the same water mass. The main part of the salinification is due to transformations of water exiting in the surface layers, and the contribution of the Barents Sea Branch is more than twice larger than the contribution of the Fram Strait Branch. On the other hand, the warming of the Arctic Ocean is due to modifications of the whole Atlantic water composing the three density classes, even though the fraction of the Barents Sea Branch that exits in the upper layer on both sides of Greenland has a dominant influence.

\subsubsection{Role of the Barents Sea}

[51] Now that water mass modifications have been quantified in our model, we determine the places where these modifications occur and try to understand the mechanisms responsible for them.

[52] We calculate freshwater and heat fluxes carried by the Barents Sea Branch as it exits the Barents Sea, across a section from Spitsbergen to Russia, following the $500 \mathrm{~m}$ isobath (that roughly corresponds to the $80^{\circ} \mathrm{N}$ parallel). Results are given in Table 4. The transit in the Barents Sea takes roughly 1 year. As they exit, water masses have undergone an important freshening and cooling, whatever the final section they reach in the Arctic. The Barents Sea is only $400 \mathrm{~m}$ deep, so the modifications are due to exchanges with the colder atmosphere, river runoff and precipitation over the Barents Sea [Schauer et al., 2002], as the Barents Sea is seasonally ice free (see Figures 10e and 10f). Table 4 shows that the heat flux transported by the Barents Sea Branch at its exit from the Barents Sea is roughly equal to the heat flux transported at its exit from the Arctic through Fram Strait or Davis Strait. This means that this branch undergoes its temperature modifications almost completely in the Barents Sea. For the salinity modifications, the picture appears more complex. Water masses that exit in the upper layer (through Davis Strait and the upper layer through Fram Strait) have also roughly reached their final salinity as soon

Table 4. Freshwater and Heat Transports at Three Passages Along the Barents Sea Branch ${ }^{\mathrm{a}}$

\begin{tabular}{lcccc}
\hline & $\begin{array}{c}\text { Exit from } \\
\text { the Arctic } \\
\text { Ocean }\end{array}$ & $\begin{array}{c}\text { Barents } \\
\text { Sea } \\
\text { (Entrance) }\end{array}$ & $\begin{array}{c}\text { Barents } \\
\text { Sea } \\
\text { (Exit) }\end{array}$ & $\begin{array}{c}\text { Exit } \\
\text { Section }\end{array}$ \\
\hline Freshwater transport (mSv) & Layer 1 & -1.4 & 21.2 & 31.5 \\
& Layer 2 & -1.5 & 0.6 & -0.9 \\
& Layer 3 & -2.2 & 1.1 & -2.5 \\
Heat transport (TW) & Davis & -1.9 & 37.2 & 42.7 \\
& Layer 1 & 12.8 & -3.1 & -2.8 \\
& Layer 2 & 10.9 & 1.9 & 1.6 \\
& Layer 3 & 15.5 & 0.2 & -0.3 \\
& Davis & 21.5 & -1.1 & -1.9 \\
\hline
\end{tabular}

\footnotetext{
${ }^{\mathrm{a}}$ See text for details.
} 

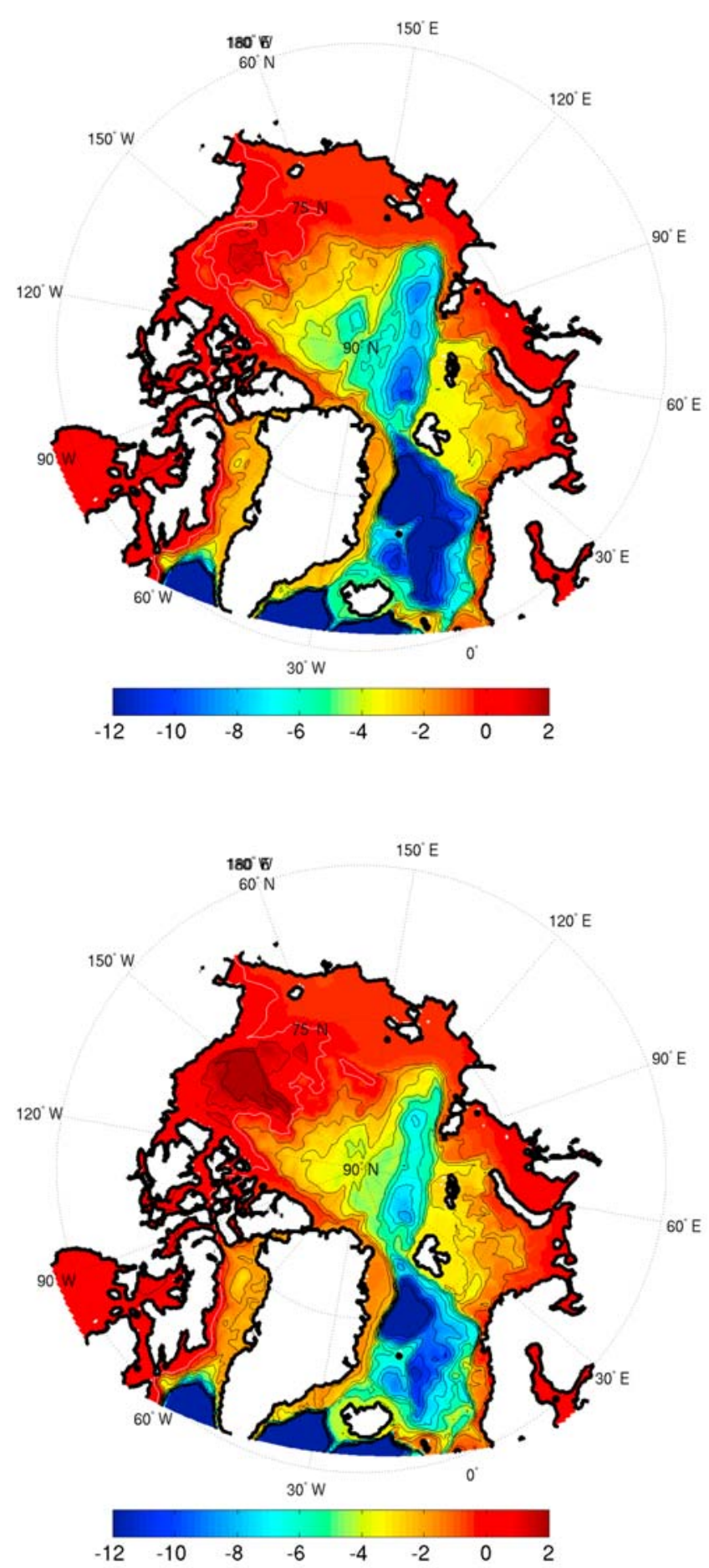

Figure 12. Model of annual mean barotropic stream function in $\mathrm{Sv}$ for the (top) $\mathrm{AO}+$ year and (bottom) $\mathrm{AO}-$ year. The contour interval is $1 \mathrm{~Sv}$.

as they leave the Barents Sea. The water masses that compose intermediate and deep layers when they leave the Arctic Ocean through Fram Strait undergo a freshening in the Barents Sea and a salinification during the rest of their travel in the Arctic Basin. Figure 10 shows that a strong temperature and salinity front exists over the Barents Sea. The front moves seasonally with the limit of the sea ice extent (not shown). Therefore, important water mass modifications (freshening and cooling) occur in the Barents Sea when the Barents Sea Branch crosses the front perpendicularly.

[53] As it leaves the Barents Sea in St. Anna Trough [Schauer et al., 2002], the modified Atlantic water meets the Fram Strait Branch that has roughly kept its initial T/S properties. The mixing of the two branches is then responsible for a part of the transformations of the Fram Strait Branch, as predicted by Smethie et al. [2000].

\section{Influence of the AO State on the Circulation Scheme}

[54] The existence of two regimes of circulation for the sea ice and the ocean surface layer has long been discussed in the literature [Proshutinsky and Johnson, 1997; Häkkinen and Proshutinsky, 2004]. Rigor et al. [2002] showed that the switch from one of these regimes to the other is closely linked to a change in the Arctic Oscillation (AO) state, whose index is defined as the leading principal component of the Northern Hemisphere Sea Level Pressure (SLP) [Thompson and Wallace, 1998]. To give some insight into how our Arctic circulation scheme would change under these two distinct regimes, we perform two additional Lagrangian experiments, using two contrasted new climatological years. These years are intended to represent the circulation during a positive or a negative AO state. They are referred to as "AO+ year" and "AO- year" in the following. We build them in the following way: the time series of the annual $\mathrm{AO}$ index (the yearly average of all months of the monthly AO index) from 1980 to 2001 is normalized to a zero mean and unit variance. Years with a normalized index larger than 1 are selected and averaged to build the AO+ year $(1989,1990,1992,1993,1995,1997$, and 2000). Years with a normalized index smaller than -1 are used to build the AO- year (1980, 1981, 1984, 1985, 1986, 1987, 1996, 1998, and 2001). In reality, however, positive and negative phases of the $\mathrm{AO}$ alternate over a decadal timescale. Thus, one has to remember that our Lagrangian calculations are based here on an idealization, in which a given $\mathrm{AO}$ phase is assumed to last long enough for water masses to transit fully in the Arctic Basin under the same AO conditions. Nevertheless, these experiments allow comparison of our results with previous observational studies in which the circulation of sea ice is contrasted during the two regimes [e.g., Rigor et al., 2002], or with modeling studies in which an OGCM is forced by typical $\mathrm{AO}+/ \mathrm{AO}-$ composite atmospheric conditions in order to determinate the ocean and sea ice canonical answer to a given AO phase [Zhang et al., 2003; Brauch and Gerdes, 2005; Condron et al., 2009].

[55] Figure 12 shows the mean Eulerian barotropic streamfunction for the $\mathrm{AO}+$ and $\mathrm{AO}-$ years. The difference between the two regimes matches what one might expect according to results of Proshutinsky and Johnson [1997] or Zhang et al. [2003]. During the positive phase of AO (Figure 12a), the Beauford Gyre contracts remarkably, and the Transpolar Drift structure shifts to the Canadian Basin and becomes predominant in the Arctic Basin. During a negative AO phase (Figure 12b), the intensity of the Beaufort Gyre is strongly enhanced whilst the Atlantic 
Table 5. Relative Contributions of the Different Branches That Contribute to the Southward Transport Through Davis Strait and Fram Strait, for $\mathrm{AO}+$ and $\mathrm{AO}-$ Years $^{\mathrm{a}}$

\begin{tabular}{|c|c|c|c|c|c|c|c|c|}
\hline & \multirow{2}{*}{\multicolumn{2}{|c|}{ Davis Strait }} & \multicolumn{6}{|c|}{ Fram Strait } \\
\hline & & & \multicolumn{2}{|c|}{ Layer 1} & \multicolumn{2}{|c|}{ Layer 2} & \multicolumn{2}{|c|}{ Layer 3} \\
\hline & $\mathrm{AO}+$ & $\mathrm{AO}^{-}$ & $\mathrm{AO}+$ & $\mathrm{AO}-$ & $\mathrm{AO}+$ & $\mathrm{AO}-$ & $\mathrm{AO}+$ & $\mathrm{AO}_{-}^{-}$ \\
\hline Bering Strait & 1.10 & 1.16 & 0 & 0 & 0.02 & 0.01 & 0 & 0 \\
\hline Davis Strait & 0.60 & 0.67 & 0 & 0 & 0 & 0 & 0 & 0 \\
\hline Fram Strait & 0.50 & 0.31 & 0.68 & 0.58 & 2.46 & 1.88 & 1.08 & 0.86 \\
\hline Barents Sea & 1.13 & 0.88 & 0.62 & 0.63 & 0.70 & 0.54 & 0.72 & 0.79 \\
\hline Total & 3.33 & 3.02 & 1.30 & 1.21 & 3.18 & 2.43 & 1.80 & 1.65 \\
\hline
\end{tabular}

${ }^{\mathrm{a}}$ Transports are given in Sv. Values smaller than $10^{-2}$ are set to 0 .

inflow and the Transpolar Drift remain in the Eurasian Basin.

[56] The results of our new Lagrangian experiments are given in Table 5. Using hydrographic data, Steele et al. [2004] showed that the circulation of Pacific halocline water is strongly influenced by the surface wind stress. Thus, the direct transfer of Pacific water from Bering Strait to Davis Strait is enhanced during the negative phase of AO. Our results are consistent with those conclusions. The export of Pacific water through Davis Strait is larger for the AO- year. The transfer of Pacific water to Fram Strait is twice larger for the $\mathrm{AO}+$ year than for the $\mathrm{AO}-$ year, as suggested by Steele et al. [2004]. However, the export on the eastern side of Greenland remains small, and does not agree with direct observations [e.g., Falck et al., 2005].

[57] As also expected from the results of Proshutinsky and Johnson [1997], the Fram Strait Branch is intensified when the AO is positive and the Transpolar Drift is then predominant. This leads to an increase of the export along both sides of Greenland, and in the three density layers in Fram Strait. The picture seems to be more complicated for the Barents Sea Branch. The export of water originating from Barents Sea is larger for the $\mathrm{AO}+$ year than for the $\mathrm{AO}-$ year through Davis Strait and the intermediate layer in Fram Strait, but smaller when we consider the upper and deeper layers in Fram Strait. We show that an important fraction of the waters following the pathway from the Barents Sea to the deep layer in Fram Strait crosses the Lomonosov Ridge and enters the Canadian Basin, where it recirculates following the topography. We do not know the influence of the AO state on the deep circulation, as the residence times in this layer are longer than the period over which the AO index keeps the same sign. However, our analysis gives evidences that, in the model, the deep circulation is also intensified in the Canadian Basin during a negative AO state, in a similar manner as the surface circulation. Concerning the surface layer export, the difference between the results of the two new Lagrangian experiments is probably due to the influence of the AO state on the circulation in the Barents Sea, as it cannot be explained by a difference in the circulation in the Arctic Basin along the Transpolar Drift. This would need to be studied in detail.

[58] Rigor et al. [2002] and Zhang et al. [2003] also showed from observations and idealized modeling that the export of freshwater and sea ice increases on both sides of Greenland during a positive AO phase. In the model, the sum of the freshwater and sea ice exports for the $\mathrm{AO}+$ year though Fram Strait and Davis Strait are 130.5 and 139.4 mSv, respectively. These amounts fall to 106 and $123.1 \mathrm{mSv}$ for the $\mathrm{AO}$ - year. Our Lagrangian experiments show that the difference is completely due to a larger freshening of Atlantic water for the $\mathrm{AO}+$ year than the $\mathrm{AO}-$ year, whereas modifications of Pacific water are roughly the same for the two experiments. In general, temperature as well as salinity modifications of the Atlantic water are stronger for the $\mathrm{AO}+$ year, even though differences are not very large. When we calculate freshwater and heat fluxes at the entrance and exit sections for the various pathways (not shown), the differences between the two sensitivity experiments in terms of freshwater and heat modifications are closely linked to the differences shown for the mass exports (Table 5). The modifications of heat and freshwater fluxes are thus larger for the intensified branches of circulation. It means that the AO state may have a bigger influence on the Arctic dynamics (the velocity field) than on specific water mass properties and transformations.

\section{Conclusions}

[59] In this paper, a quantitative Lagrangian analysis has been applied to the 3D output of a simulation using the global ocean/sea ice high-resolution DRAKKAR model $\left(1 / 4^{\circ}\right.$, which is about $12 \mathrm{~km}$ in the Arctic Ocean). We propose for the first time a quantitative scheme of the Arctic circulation and related water mass modifications, for a climatological year built over the 1980-2001 period. A validation of the model was carried out in the present paper as well as in Lique et al.'s [2009] study, comparing the model Eulerian fields with direct observations (when and where available) and with previous model studies (such as those published within the AOMIP project). Although the model Eulerian fields are shown to reproduce fairly well the Arctic Ocean circulation and water mass properties, which adds credibility to our Lagrangian analysis, the results are model and method dependent. The quantification of the water mass transformations might be affected by the the use a very strong restoring to a climatological surface salinity. This study is only a first step toward a coherent scheme of the Arctic circulation.

[60] The study mainly focuses on determining the origins of water masses exported from the Arctic Ocean along both sides of Greenland (through Davis Strait on the western side, and Fram Strait on the eastern side). At Davis Strait, the exports are composed of water of Pacific and Atlantic origins in equal part. On the other hand, in the model, the exports through Fram Strait are composed of water entering the Arctic within a Fram Strait Branch and a Barents Sea Branch, with only very small traces of Pacific water. Both branches export an equal amount of water in the upper and deep layer, whereas the exported intermediate water mainly comes from the Fram Strait Branch (80\%).

[61] The study reveals that, in the model, Pacific water entering the Arctic exits on the western side of Greenland and is transferred quickly $(\mathrm{O}(10$ years $))$ to the North Atlantic. It transits through the Beaufort Gyre in the upper layer, where gradual warming and salinification occur. Thus, we are unable to simulate a transfer of Pacific water from Bering Strait to Fram Stait, though this transfer has been evidenced by several observers [Jones et al., 1998, 2003; Taylor et al., 2003]. One could find this result a bit 
surprising, especially when one knows that the model inflow through Bering Strait is overestimated by about $20 \%$, so we discussed the possible reasons for this model deficiency (also found for instance in the numerical study of Karcher and Oberhuber [2002]). The most likely explanation is the underestimation of the current on the shelf along the Canadian Coast, through which Pacific water might be transferred to Fram Strait.

[62] Atlantic water exiting in the surface layer along both sides of Greenland remains about 10 years in the Arctic Basin, and undergoes a cooling and an important freshening (especially for the Barents Sea Branch). This transformation represents the most important source of salt for the Arctic Ocean. In the model, the fraction of these waters that exits through Davis Strait is found to enter the Canadian Basin in the Laptev Sea. Atlantic water exiting through the intermediate and deep layers in Fram Strait follows different possible pathways in the Arctic, with trajectories being subject to topographic constraints. The intermediate layer is mainly composed of the Barents Sea Branch, and these waters need about 30 years to travel in the Arctic, where their temperature strongly decreases whilst their salinity remains roughly constant. As for the exports in the deeper layer, the travel time (from 1 to 1000 years) depends strongly on the followed pathway and the transformations are less important (only the Barents Sea Branch undergoes an important cooling).

[63] The role of the Barents Sea in the transformations of the Atlantic inflow has been underlined. The model results suggest that the Barents Sea Branch is almost fully transformed there in less than 1 year, due to exchanges with the very cold atmosphere. A fraction of the modifications of the Fram Strait Branch is due to turbulent mixing with the Barents Sea Branch, as both branches converge in the St. Anna Trough at the exit from the Barents Sea. As the Arctic is becoming more and more ice free, one can imagine that such strong and quick transformations could also occur over the other Arctic shelves.

[64] Our study provides a picture of the mean circulation scheme, and this scheme is found to be relatively robust to a change in the AO state. Although this description of the Arctic mean state is prerequisite, thorough study of the variability of this scheme is needed to allow better understanding of the Arctic Ocean response to climate change. For instance, finer scales, both in time and space, have to be investigated, as our dynamic scheme might change if a higher-resolution model with higher-frequency outputs was used for the Lagrangian analysis. A complementary approach to this study could also be the simulation of passive tracers, taking into account both the advective and diffusive components of the water mass trajectories.

[65] Acknowledgments. We thank Bruno Tremblay (editor), Greg Holloway, and an anonymous reviewer for their great help and their important comments that have contributed to improve significantly our manuscript. We also thank C. Herbaut and J. Cuny for very helpful comments and suggestions on an earlier version. This study uses numerical experiments carried out within the DRAKKAR project. The simulation has been run at the IDRIS CNRS-GENCI computer center in Orsay, France, by J.M. Molines. C. Lique is supported by CNES and IFREMER. A.M. Treguier, B. Blanke, and N. Grima are supported by CNRS.

\section{References}

Aagaard, K., and E. Carmack (1989), The role of sea ice and other fresh water in the Arctic circulation, J. Geophys. Res., 94, 14,485-14,498.

Aagaard, K., and P. Greisman (1975), Toward new mass and heat budgets for the Arctic Ocean, J. Geophys. Res., 80(27), 3821-3827.

Barnier, B., et al. (2006), Impact of partial steps and momentum advection schemes in a global ocean circulation model at eddy permitting resolution, Ocean Dyn., 56, 543-567, doi:10.1007/s10236-006-0082-1.

Blanke, B., and S. Raynaud (1997), Kinematics of the Pacific Equatorial Undercurrent: A Eulerian and Lagrangian approach from GCM results, J. Phys. Oceanogr., 27, 1038-1053.

Blanke, B., M. Arhan, G. Madec, and S. Roche (1999), Warm water paths in the Equatorial Atlantic as diagnosed with a general circulation model, J. Phys. Oceanogr., 29, 2753-2768.

Blanke, B., S. Speich, G. Madec, and K. Döös (2001), A global diagnostic of interocean mass transfers, J. Phys. Oceanogr., 31, 1623-1632.

Blanke, B., M. Arhan, S. Speich, and K. Pailler (2002), Diagnosing and picturing the North Atlantic segment of the global conveyor belt by means of an ocean general circulation model, J. Phys. Oceanogr., 32, 1430-1451.

Blanke, B., M. Arhan, and S. Speich (2006), Salinity changes along the upper limb of the Atlantic thermohaline circulation, Geophys. Res. Lett., 33, L06609, doi:10.1029/2005GL024938.

Brauch, J. P., and R. Gerdes (2005), Response of the northern North Atlantic and Arctic oceans to a sudden change of the North Atlantic Oscillation, J. Geophys. Res., 110, C11018, doi:10.1029/2004JC002436.

Brodeau, L., B. Barnier, T. Penduff, A. M. Treguier, and S. Gulev (2010), An evaluation of ERA-40 and CORE atmospheric variables as drivers of global ocean models, in revision for Ocean Modell., 31, 88-104.

Coachman, L. K., and K. Aagaard (1974), Physical oceanography of Arctic and Subarctic seas, in Marine Geology and Oceanography of the Arctic Seas, edited by Y. Herman, pp. 1-72, Springer, New York.

Condron, A., P. Winsor, C. Hill, and D. Menemenlis (2009), Simulated response of the Arctic freshwater budget to extreme NAO wind forcing, J. Clim., 22, 2422-2437.

Cuny, J., P. B. Rhines, and R. Kwok (2005), Davis Strait volume, freshwater and heat fluxes, Deep Sea Res. Part 1, 52, 519-542.

Dai, A., and K. Trenberth (2002), Estimates of freshwater discharge from continents: Latitudinal and seasonal variations, J. Hydrometeorol., 3, 660-687.

Dickson, R. R., J. Meincke, and P. Rhines (2008), Arctic-subArctic Ocean fluxes: Defining the role of the northern seas in climate. A general introduction, in Arctic-Subarctic Ocean Fluxes, edited by R. R. Dickson, J. Meincke, and P. Rhines, pp. 1-12, Springer, New York.

Döös, K. (1995), Inter-Ocean exchange of water masses, J. Geophys. Res. $100,13,499-13,514$.

Ekwurzel, B., P. Schlosser, R. A. Mortlock, R. G. Fairbanks, and J. H. Swift (2001), River runoff, sea ice meltwater, and Pacific water distribution and mean residence times in the Arctic Ocean, J. Geophys. Res., 106(C5), 9075-9092.

Ezraty, R., F. Girard-Ardhuin, J. F. Piolle, L. Kaleschke, and G. Heygster (2007), Arctic and Antarctic sea ice concentration and Arctic sea ice drift estimated from special sensor microwave imager data: User's manual, version 2.1., technical report, Fr. Res. Inst. for Exploit. of the Sea, Plouane, France.

Fahrbach, E., J. Meincke, S. Osterhus, G. Rohardt, U. Schauer, V. Tverberg, and J. Verduin (2001), Direct measurements of volume transports through Fram Strait, Polar Res., 20(2), 217-224.

Falck, E., G. Kattner, and G. Budeus (2005), Disappearance of Pacific water in the northwestern Fram Strait, Geophys. Res. Lett., 32, L14619, doi:10.1029/2005GL023400.

Friocourt, Y., S. Drijfhout, B. Blanke, and S. Speich (2005), Water mass export from Drake passage to the Atlantic, Indian and Pacific Oceans: A Lagrangian model analysis, J. Phys. Oceanogr., 35, 1206-1222.

Gerdes, R., and U. Schauer (1997), Large-scale circulation and water mass distribution in the Arctic Ocean from model results and observations, J. Geophys. Res., 102(C4), 8467-8483.

Häkkinen, S., and A. Proshutinsky (2004), Freshwater content variability in the Arctic Ocean, J. Geophys. Res., 109, C03051, doi:10.1029/ 2003JC001940.

Holloway, G. (1992), Representing topographic stress for large scale ocean models, J. Phys. Oceanogr., 22, 1033-1046.

Holloway, G., and A. Proshutinsky (2007), Role of tides in Arctic ocean/ice climate, J. Geophys. Res., 112, C04S06, doi:10.1029/2006JC003643.

Holloway, G., and Z. Wang (2009), Representing eddy stress in an Arctic Ocean model, J. Geophys. Res., 114, C06020, doi:10.1029/ 2008JC005169. 
Holloway, G., et al. (2007), Water properties and circulation in Arctic Ocean models, J. Geophys. Res., 112, C04S03, doi:10.1029/ 2006JC003642.

Jones, E. P., B. Rudels, and L. G. Anderson (1995), Deep waters of the Arctic Ocean: Origins and circulation, Deep Sea Res. Part I, 42, 737-760.

Jones, E. P., L. G. Anderson, and J. H. Swift (1998), Distribution of Atlantic and Pacific waters in the upper Arctic Ocean: Implications for circulation, Geophys. Res. Lett., 25(6), 765-768.

Jones, E. P., J. H. Swift, L. G. Anderson, M. Lipizer, G. Civitarese, K. K. Falkner, G. Kattner, and F. McLaughlin (2003), Tracing Pacific water in the North Atlantic, J. Geophys. Res., 108(C4), 3116 , doi:10.1029/2001JC001141.

Karcher, M., F. Kauker, R. Gerdes, E. Hunke, and J. Zhang (2007), On the dynamics of Atlantic Water circulation in the Arctic Ocean, J. Geophys. Res., 112, C04S02, doi:10.1029/2006JC003630.

Karcher, M. J., and J. M. Oberhuber (2002), Pathways and modification of the upper and intermediate waters of the Arctic Ocean, J. Geophys. Res. 107(C6), 3049, doi:10.1029/2000JC000530.

Koch-Larrouy, A., G. Madec, B. Blanke, and R. Molcard (2008), Water mass transformation along the indonesian throughflow in an OGCM, Ocean Dyn., 58, 289-309.

Large, W., and S. Yeager (2004), Diurnal to decadal global forcing for ocean and sea-ice models: The datasets and flux climatologies, Tech. Note NCAR/TN-460+STR, Natl. Cent. for Atmos. Res., Boulder, Colo.

Le Sommer, J., T. Penduff, S. Theetten, G. Madec, and B. Barnier (2009), How momentum advection schemes influence currenttopography interactions at eddy permitting resolution, Ocean Modell., 29(1), 1-14.

Lique, C., A. Treguier, M. Scheinert, and T. Penduff (2009), A modelbased study of ice and freshwater transport variability along both sides of Greenland, Clim. Dyn., 33, 685-705, doi:10.1007/s0038200805107.

Madec, G. (2008), NEMO Ocean engine, Note Pôle Modélisation 27, Inst. Pierre-Simon Laplace, Paris.

Maslowski, W., D. Marble, W. Walczowski, U. Schauer, J. L. Clement, and A. J. Semtner (2004), On climatological mass, heat, and salt transports trough the Barents Sea and Fram Strait from a pan-Arctic coupled iceocean model simulation, J. Geophys. Res., 109, C03032, doi:10.1029/ 2001JC001039.

Mauritzen, C. (1996), Production of dense overflows waters feeding the North Atlantic across the Greenland-Scotland Ridge. Part 1: Evidence for a revised circulation scheme, Deep Sea Res. Part I, 43, 769-806.

Molines, J. M., B. Barnier, T. Penduff, L. Brodeau, A. M. Treguier, S. Theetten, and G. Madec (2006), Definition of the interannual experiment ORCA025-G70, 1958-2004, Rep. LEGI-DRA-2-11-2006, Lab. des Ecoulements Gophys. et Ind., Grenoble, France. (Available at www.ifremer.fr/lpo/drakkar.)

Nansen, F. (Ed.) (1902), The Norwegian North Polar Expedition 1893-1896: Scientific Results, vol. 5, Longmans, Green, London.

Nazarenko, L., G. Holloway, and N. Tausnev (1998), Dynamics of transport of "Atlantique signature" in the Arctic Ocean, J. Geophys. Res., 103, 31,003-31,015.

Ostlund, H. G., and G. Hut (1984), Arctic Ocean water mass balance from isotope data, J. Geophys. Res., 89, 6373-6381.

Ostlund, H. G., G. Possnert, and J. H. Swift (1987), Ventilation rate of the deep Arctic Ocean from Carbon 14 data, J. Geophys. Res., 92, 3769-3777.

Proshutinsky, A., et al. (2005), Arctic Ocean Study: Synthesis of model results and observations, Eos Trans. AGU, 86(40), 368, 371.

Proshutinsky, A. Y., and M. A. Johnson (1997), Two circulation regimes of the wind-driven Arctic Ocean, J. Geophys. Res., 102, 12,493-12,514.

Proshutinsky, A. Y., R. H. Bourke, and F. A. McLaughlin (2002), The role of the Beaufort Gyre in Arctic climate variability: Seasonal to decadal climate scales, Geophys. Res. Lett., 29(23), 2100, doi:10.1029/ 2002 GL015847.

Rigor, I. G., J. M. Wallace, and R. L. Colony (2002), Response of sea ice to the Arctic Oscillation, J. Clim., 15, 2648-2663.
Rudels, B., E. P. Jones, L. G. Anderson, and G. Kattner (1994), On the intermediate depth waters of the Arctic Ocean, in The Polar Oceans and Their Role in Shaping the Global Environment, Geophys. Monogr. Ser., vol. 85, edited by O. M. Johannessen et al., pp. 33-46, AGU, Washington, D. C.

Schauer, U., H. Loeng, B. Rudels, V. K. Ozhigin, and W. Dieck (2002), Atlantic water flow through the Barents and Kara seas, Deep Sea Res. Part I, 49, 2281-2298.

Schauer, U., E. Fahrbach, S. Osterhus, and G. Rohardt (2004), Arctic warming through the Fram Strait: Oceanic heat transport from 3 years of measurements, J. Geophys. Res., 109, C06026, doi:10.1029/ 2003JC001823.

Schlosser, P., D. Bauch, R. Fairbanks, and G. Bönisch (1994), Arctic river runoff: Mean residence time on the shelves and in the halocline, Deep Sea Res. Part I, 41, 1053-1068.

Schlosser, P., J. H. Swift, D. Lewis, and S. L. Pfirman (1995), The role of the large-scale Arctic Ocean circulation in the transport of contaminants, Deep Sea Res. Part II, 42(6), 1341-1367.

Simonsen, K., and P. Haugan (1996), Heat budgets of the Arctic mediterranean and sea surface heat flux parameterizations for the Nordic seas, J. Geophys. Res., 101, 6553-6576.

Smethie, W. M., P. Schlosser, G. Bönisch, and T. S. Hopkins (2000), Renewal and circulation of intermediate waters in the Canadian Basin observed on the SCICEX 96 cruise, J. Geophys. Res., 105, 1105-1121.

Spall, M. A., R. S. Pickart, P. S. Fratantoni, and A. J. Plueddemann (2008), Western Arctic shelbreak eddies: Formation and transport, J. Phys. Oceanogr., 38(8), 1644-1668.

Speich, S., B. Blanke, and G. Madec (2001), Warm and cold routes of an OGCM thermohaline conveyor belt, Geophys. Res. Lett., 28(2), 311-314.

Steele, M., R. Morley, and W. Ermold (2001), PHC: A global ocean hydrography with a high quality Arctic Ocean, J. Clim., 14, 2079-2087.

Steele, M., J. Morison, W. Ermold, I. Rigor, M. Ortmeyer, and K. Shimada (2004), Circulation of summer Pacific halocline water in the Arctic Ocean, J. Geophys. Res., 109, C02027, doi:10.1029/2003JC002009.

Steiner, N., et al. (2004), Comparing modeled streamfunction, heat and freshwater content in the Arctic Ocean, Ocean Modell., 6, 265-284.

Taylor, J. R., K. K. Falkner, U. Schauer, and M. Meredith (2003), Quantitative considerations of dissolved Barium as a tracer in the Arctic Ocean, J. Geophys. Res., 108(C12), 3374, doi:10.1029/2002JC001635.

The DRAKKAR Group (2007), Eddy-permitting ocean circulation hindcasts of past decades, Clim. Var. Predict. Exch. Rep. 42, Int. CLIVAR Proj. Off., Southhampton, U. K.

Thompson, D. W. J., and J. M. Wallace (1998), The Arctic Oscillation signature in the wintertime geopotential height and temperature fields, Geophys. Res. Lett., 25, 1297-1300.

Timmermann, R., H. Goose, G. Madec, T. Fichefet, C. Ethe, and V. Duliere (2005), On the representation of high latitude processes in the ORCA-LIM global coupled sea ice-ocean model, Ocean Modell., 8, 175-201.

Valdivieso Da Costa, M., and B. Blanke (2004), Lagrangian methods for flow climatologies and trajectory error assessment, Ocean Modell., 6, 335-358.

Woodgate, R. A., K. Aagaard, and T. J. Weingartner (2006), Interannual changes in the Bering Strait fluxes of volume, heat and freshwater between 1991 and 2004, Geophys. Res. Lett., 33, L15609, doi:10.1029/ 2006GL026931.

Zhang, X., M. Ikeda, and J. E. Walsh (2003), Arctic sea ice and freshwater changes driven by the atmospheric leading mode in a coupled sea iceocean model, J. Clim., 16(13), 2159-2177.

B. Blanke, N. Grima, C. Lique, and A. M. Treguier, Laboratoire de Physique des Océans, UMR 6523, UBO, CNRS, IFREMER, IRD, Centre de Brest, BP 70, F-29280 Plouzane, France. (camille.lique@ifremer.fr) 